\title{
Research Paper \\ Comparing the Effectiveness of Social-Emotional Learning Curriculum of Strong Kids on Sense of Belonging to School among Primary School Children of Affluent and Deprived areas of Hamedan
}

\author{
Rahim Badri Gargari ${ }^{* 1}$, Yosef Adib ${ }^{1}$, Touraj Hashemi ${ }^{1}$, Elham Erfani Adab ${ }^{4}$ \\ 1. Professor, Department of Educational Sciences, Faculty of Psychology and Educational Sciences, Tabriz University, Iran \\ 2. Ph.D. Student of Educational Psychology, Faculty of Psychology and Educational Sciences, Tabriz University, Iran Iran
}

Citation: Badri Gargari R, Adib Y, Hashemi T, Erfani Adab E. Comparing the effectiveness of social-emotional learning curriculum of strong kids on sense of belonging to school among primary school children of affluent and deprived areas of hamedan. Quarterly Journal of Child Mental Health. 2020; 6(4): 179-193.

http://dx.doi.org/10.29252/jcmh.6.4.17

\section{A R T I C L E I N F O}

\begin{tabular}{l}
\hline Keywords: \\
Sense of belonging to \\
school, \\
social-emotional learning \\
program, \\
strong kids, \\
affluent, \\
deprived
\end{tabular}

Received: 13 May 2018

Accepted: 20 Sep 2018

Available: 4 Mar 2020

\section{A B S T R A C T}

Background and Purpose: Sense of connectedness with school is defined as individuals' attitudes that enhance their affinity with school environment and is improved through social-emotional Learning. The current research aimed to assess the effectiveness of strong kids' social-emotional learning program in the sense of belonging to school of primary school students in Hamedan's affluent and deprived districts.

Method: The study was carried out by following quasi-experimental unequal groups design. To choose the sample from the statistical population of male five graders in the academic year of 2017 2018 , the researcher selected four five-grade classes, purposively chosen from deprived (2 classes and 51 subjects) and affluent ( 2 classes and 45 subjects) districts and randomly assigned as control and experimental groups. As a pre-test, sense of belonging to school questionnaire (Brew, Beatty, Watt, 2004) was administered, followed by the treatment which included 12 instructional sessions (each continuing for 60 minutes in a 3-month period) and covered strong kids' social-emotional learning program for the experimental groups. Finally, the same questionnaire was administered as a post-test across the four groups.

Results: The results indicated that sense of connectedness with school and its constituent components (teacher support, engagement in the broader community, the observation of fairness and respect at school, relatedness of self with school, academic engagement, positive sense to school) are higher in experimental groups than those of control groups $(\mathrm{p}<.05)$. In addition, it was found that strong kids' social-emotional instruction influenced sense of connectedness with school and its constituent components (teacher support, engagement in the broader community, fairness and safety, relatedness of self with school, academic engagement, and positive sense to school) equally benefitted the students in deprived and affluent district's students.

Conclusion: The staff who provide an environment that allows students to grow emotionally, socially, mentally, and educationally, reinforce the sense of belonging to school. If the students feel to be cared and supported by the school, they will have better educational progress and show a decrease in risky behaviors.

\footnotetext{
* Corresponding author: Rahim Badri Gargari, Professor, Department of Educational Sciences, Faculty of Psychology and Educational Sciences, Tabriz University, Iran.

E-mail addresses: Badri_rahim@yahoo.com
} 


\section{اثربخشى آموزش برنامه يادكيرى اجتماعى - هيجانى كود كان قوى بر احساس تعلق به مدرسه دانش آموزان مقطع ابتدايى مناطق برخورئ اجمودار و محروم شهر همدان}

\section{رحيم بدرى كر كرى*'، يوسف اديب'، تورج هاشمى'، الهام عرفانى آداب'}

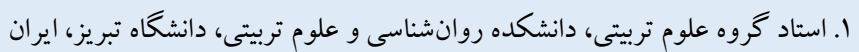

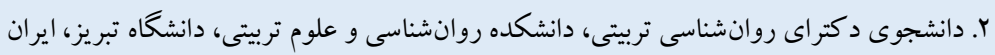

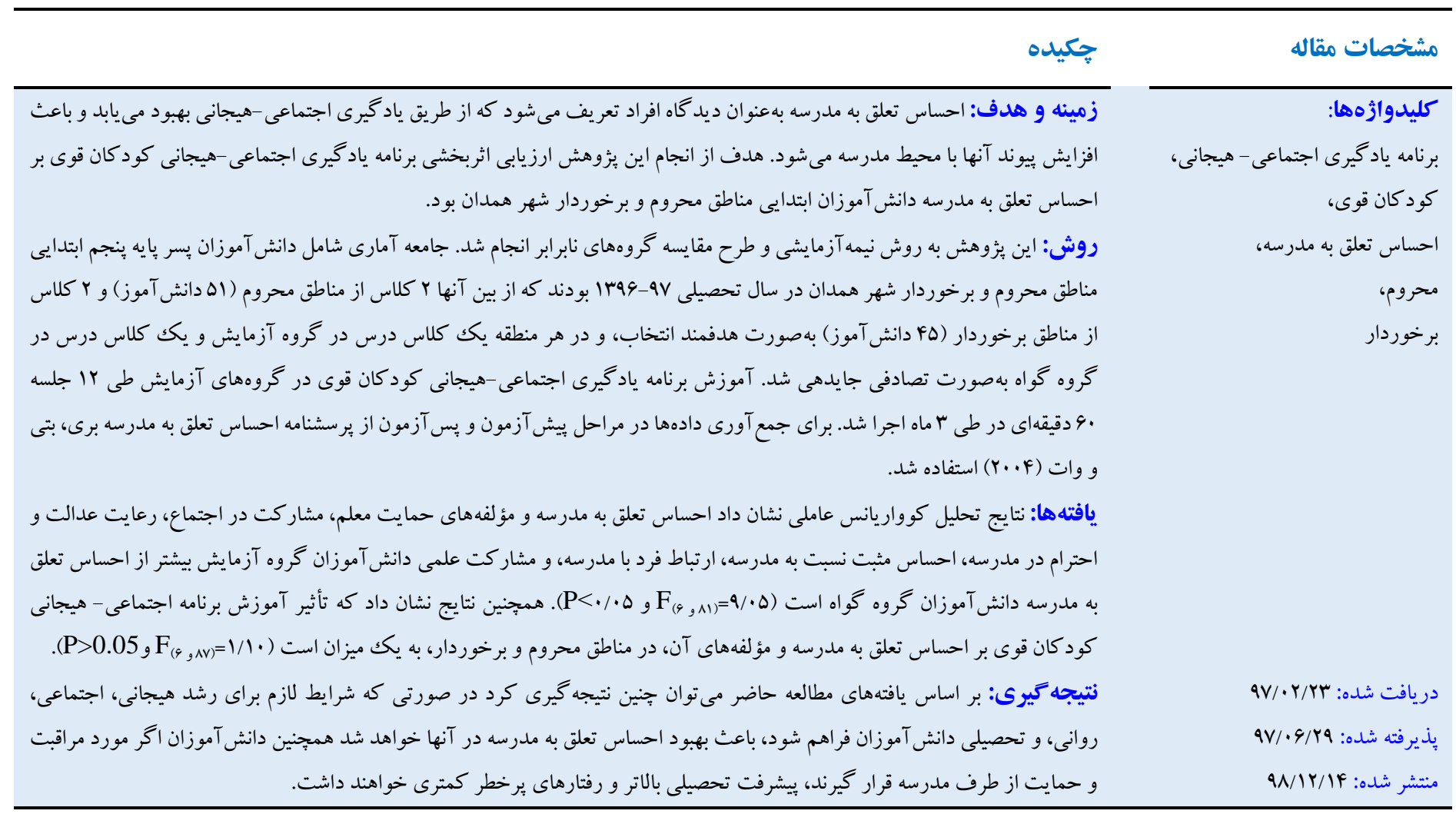

* نويسنده مسئول: رحيم بدرى گر گرى، استاد گروه علوم تربيتى، دانشكده روانشناسى و علوم تربيتى، دانشكاه تبر يز، ايران.

رايانامه: Badri_rahim@yahoo.com

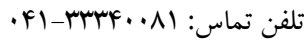




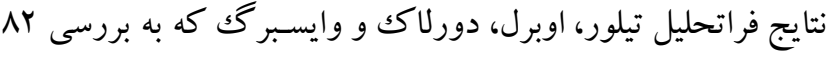

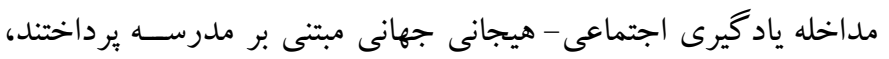

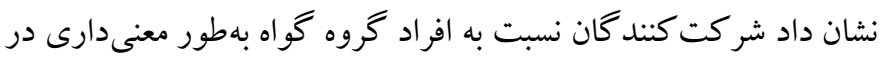

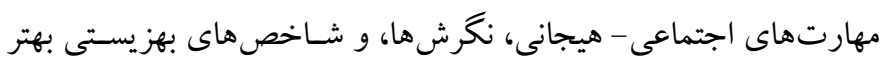

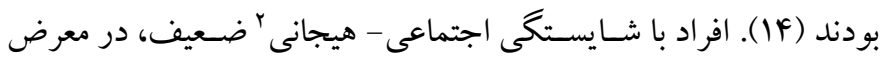

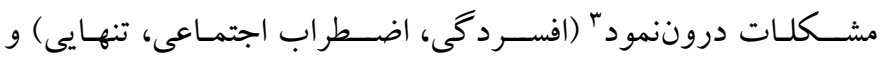

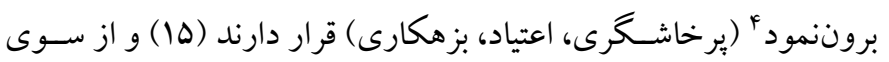
ديخر بيشرفت تحصيلى بايين ترى دارند (19).

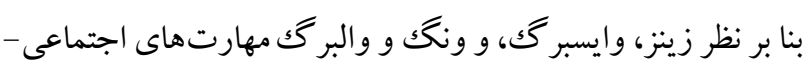

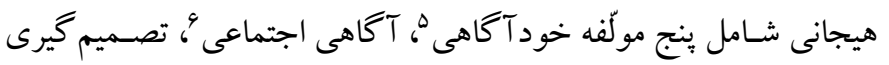

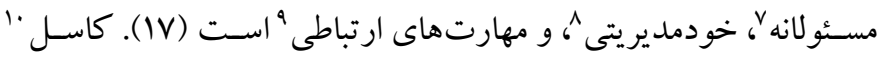

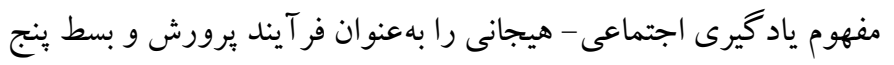

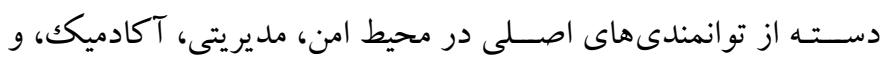
محيطهاى آموزش مشار كتى توصيف مى كند (1N). طبق تعريف كاسل اين بنج مهارت عبارتاند از: خود آكاهى (توانايى در ارزيابى صسحيح احسـاسـات، علائق، ارزشها و نقاط ضعف، حفظ حس اعتماد به خود و

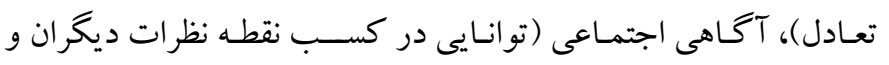

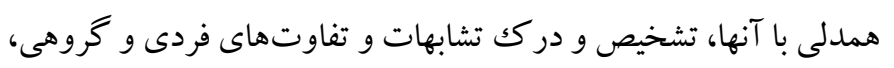

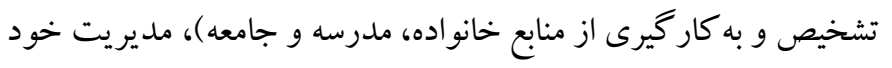

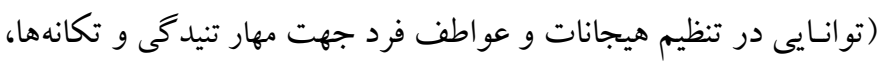

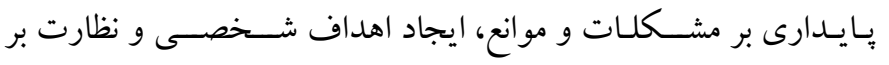

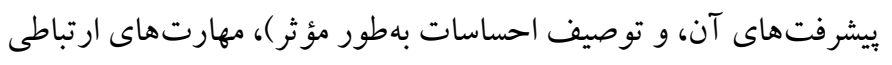

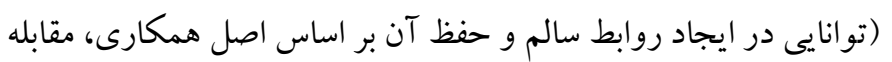

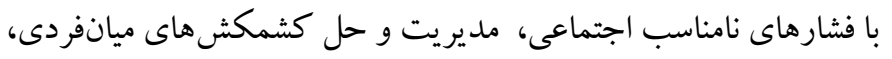
درخواسـت كمكك در صورت ضرورت و نياز)، و تصميم گيرى مسئولانه

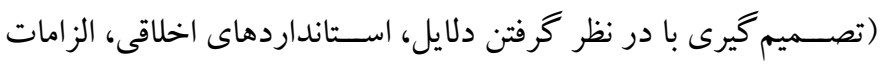

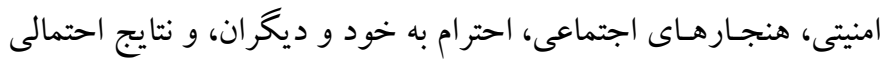
عملكر دهاى مختلف) (1) (1).

6. Social awareness

7. Responsible decision making

8. Self-management

9. Relationship skills

10. Casel مقلdo

احســاس تعلق به مدرســه' به عنوان نوع رابطه دانش آموزان با مدرســه تعريف شـده اسـت كه براى بيشـرفت آنان ضـرورت دارد ( (1). همجينين

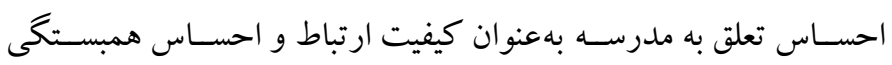

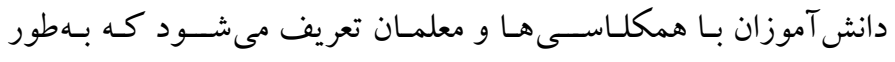
غيرمستقيم با موفقيت تحصيلى دانش آموزان ارتباط دارد (Y). اين مفهوم به اين موضـوع اشاره دارد كه دانش آموزان جه احساسى نسبت به مدرسه خود دارند و تعلقى كه با همســالان، معلمان، و كادر آموزشــى مدرســهـ

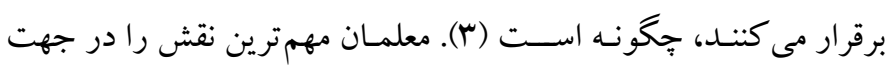
افزايش تعلق به مدرسـه دانش آموزان ايفا مى كنند. آنها با خلق موقعيت ها و فرصـتهايى به منظور كمكك به دانش آموزان براى تجربه احساس تعلق بيشتر به مدرسه، همكلاسى ها، و ديكر معلمان، وظيفه خطيرى را عهدهدار

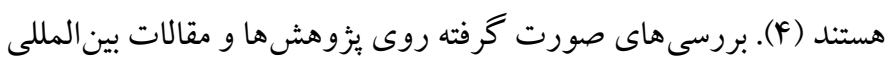
حاكى از اين اسـت كه كود كان داراى احسـاس تعلق بايين به مدرسه، در مـدارس احســاس بيخانكى مى كنند (ه). اين مســــله بهنوبه خود منجر به بيامدهاى منفى ديكرى مانند بيشرفت تحصيلى ضعيف و در نهايت ترك تحصيل مىشود. در مقابل، حس تعلق بالا به مدرسه مى تواند به انكيزش و يايه هاى تحصسيلى بالاترى منجر شـود (9). احسـاس تعلق به مدرسـه عامل مهمى در ســلـامت روانى دانش آموزان اســـ؛ به طورى كه يايين بودن احسـاس تعلق به مدرسـه با علائم اضـطر اب، افسـردگى، و حتى بيشبينى افسردگى در يكك سـال بعدى نيز مرتبط است (V). بيشتر يثزوهش ها نشان دادند كه هر جققدر احساس تعلق به مدرسه در فردى بالاتر باشد، مشكلات

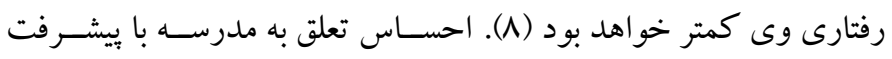
تحصــيلى دانش آموزان ارتبـاط دارد و از طرفى بـا اســتفاده از ياد گيرى اجتماعى - هيجانى بهبود مى يابد (9). نتايج يزوهش هاى مختلف نيز مؤيد تأثير برنامه يادگيرى اجتماعى - هيجانى بر بهبود احسـاس تعلق به مدرسـه

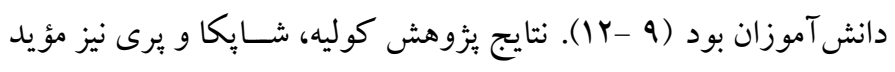

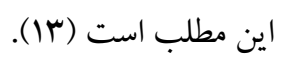

1.Sense of belonging to school

2. Social-emotional competence

3. Internalizing

4. Externalizing

5. Self-awareness 
بلندمدت، احتمال آمادكى براى ورود به دانشــاه، موفق بودن در حرفه، داشـتن روابط مثبت و سـلامت روانى بهتر، و تبديل شــدن به شـهروندان

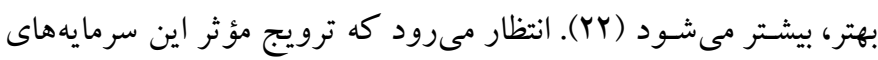

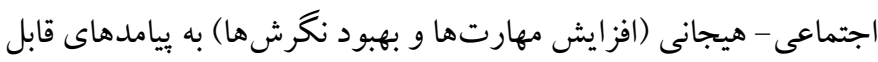

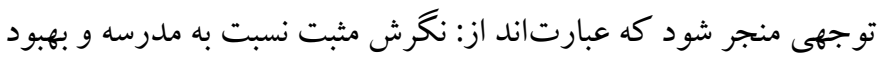

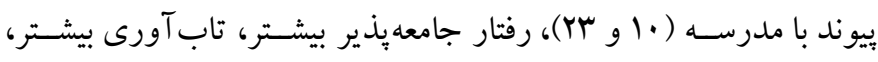
احســاس تعلق به مدرسـهـ بالاتر، افزايش عملكرد تحصـيلى، مشـكلات

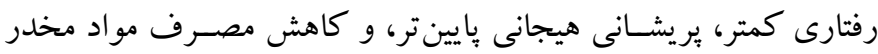

.$(Y \Delta, Y Y)$

ياد گيرى اجتماعى - هيجانى عاملى بسيار مهم براى هدف قرار دادن

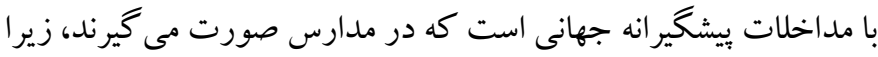

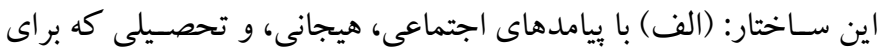

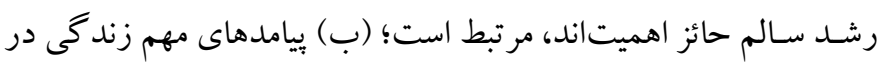

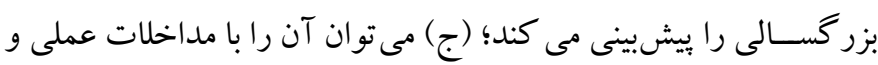
مقرونبهصرفه بهبود داد؛ و (د) نقش بسيار مهمى در روند تغيير رفتار، ايفا مى كند (Y)) علاوه بر اين، ياد گيرى اجتماعى- هيجانى در ميان بسـيارى

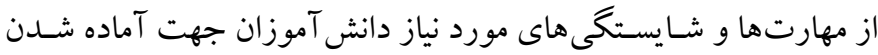

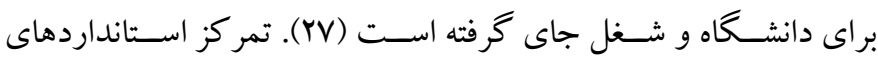

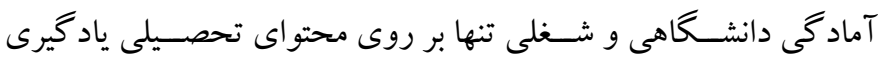

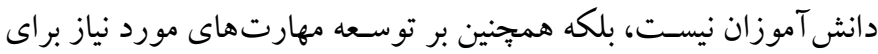

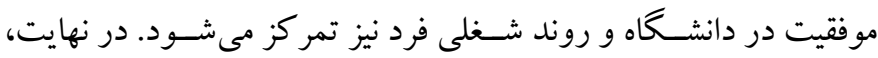

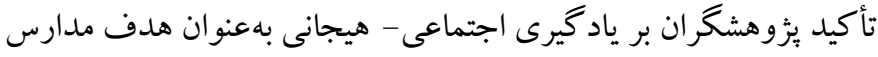

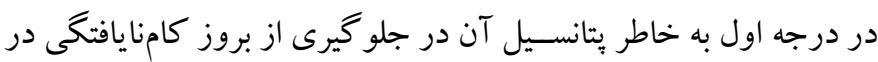

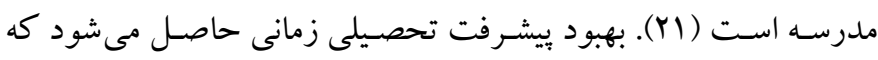

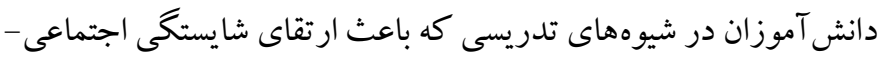
هيجانى مى شـود، شــركت كنند. يُزوهشهاى انجام شـــده در خارج از

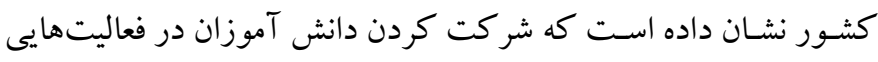

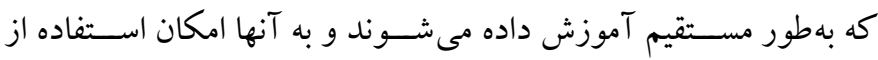

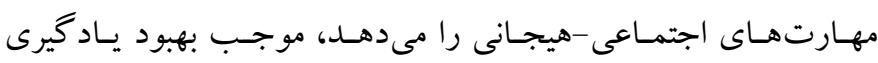

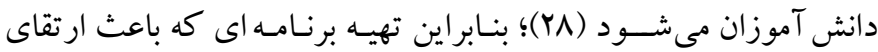

يـادگيـرى اجتـمـاعى - هيجـانى يكى از اهــاف اســاسـى

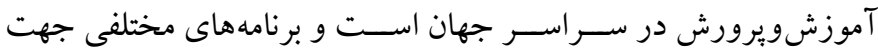
آموزش آن در كشورهاى مختلف تدوين و اجرا شده است، اما در ايران

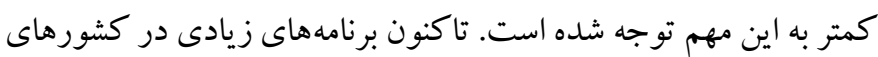
مختلف جهت ياد گيرى اجتماعى - هيجانى طراحى و تدوين شـده اسـت كه يكى از آنها برنامه مجموعه محتو اي درسى كود كان قوى ' (19) است

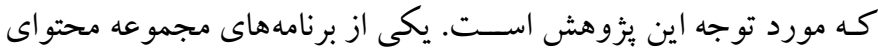

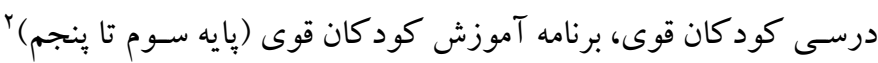
اســت. اين برنامه در درجه اول به اين دليل انتخاب مى شـــود كه به بهنوان

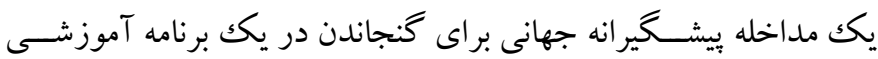

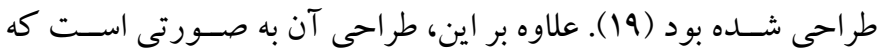

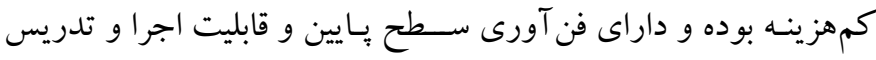

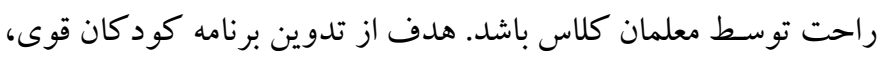

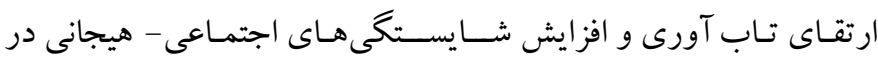
دانش آموزان اسـت. مرل نشـان داد هر جند برنامه كود كان قوى مى تواند براى ارتقاى تاب آورى در كودكان در معرض خطر مورد اســفاده قرار

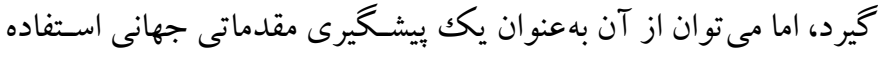

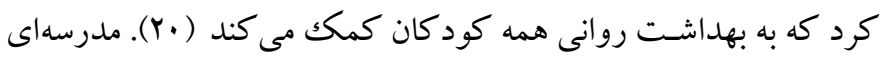
كه در آن اصسول ياد گيرى اجتماعى - هيجانى بهصسورت مدرسـه گسـتر

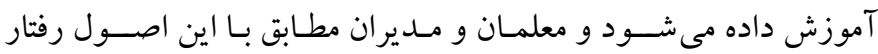

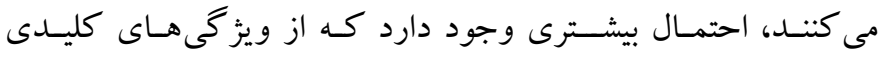

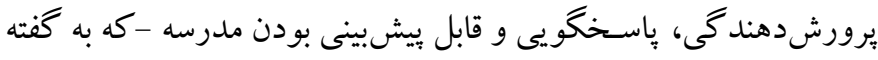

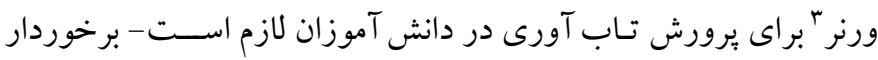
باشـــد (YI). همجينين طراحى اين برنامه تحصسيلى براى اسـتفاده، كو تاه، مقرون بهصرفه و آسان است.

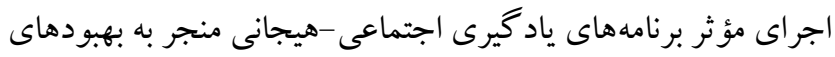

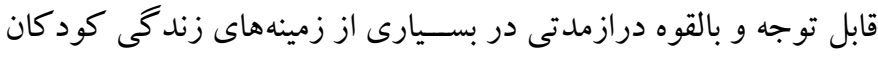

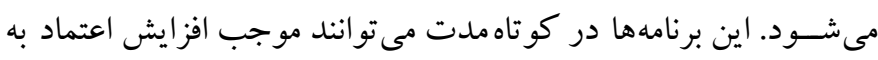

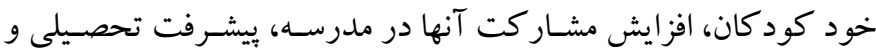

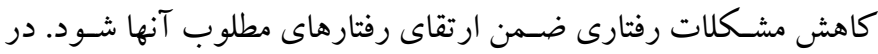


بـا توجـه بـه حجم نمونه مكفى ها تا .بـ نفر براى هر گروه در تحقيقات

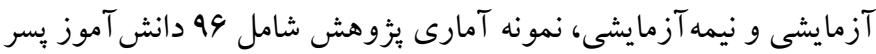

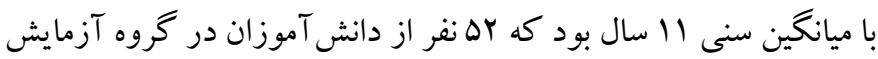

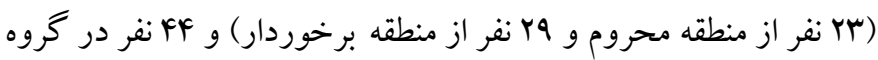

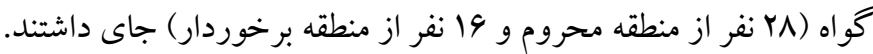

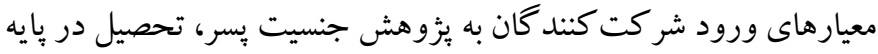

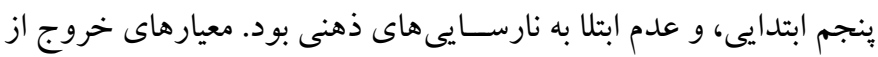

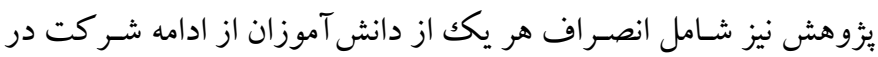
برنامه و غيبت بيش از Y جلسه بود.

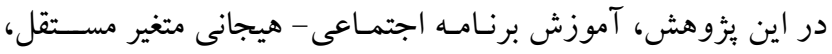

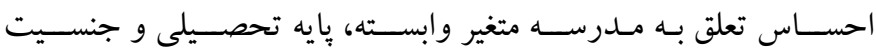
دانش آموزان متغيرهاى كنترل، و منطقه آموزشـى (محروم يا برخوردار)

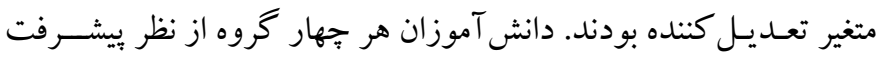

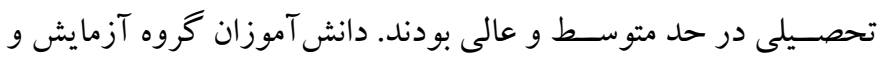

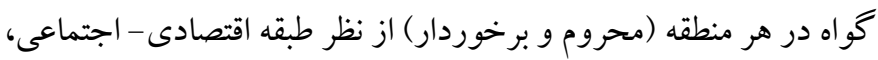
مشـكلات دروننمود و بروننمود، و جِكونگى روابط با همسالان، همسان

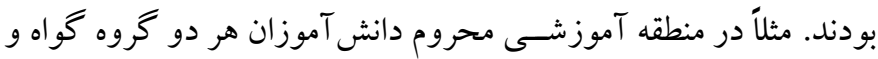

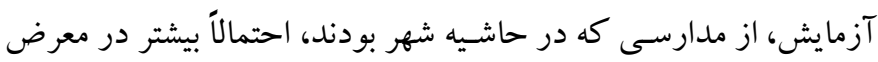
خطرات اجتماع بودند، و طبقه اقتصـادى - اجتماعى (تحصسيلات والدين، شــل والدين، در آمد ماهانه، و محل سـكونت) خانواده آنها بايين تر از

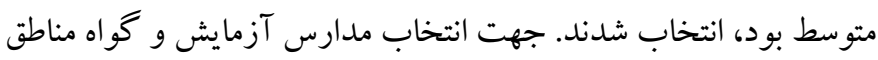
برخوردار نيز از مدارسـى كه از نظر امكانات مدرسـه كاملاً قوى بوده و خانو اده اين دانش آموزان از نظر طبقه اقتصـادى - اجتماعى (تحصـيلات

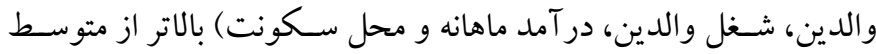
بودند، انتخاب شـــند. دانش آموزان منطقه محروم حاشـيه شــهر بنا بر

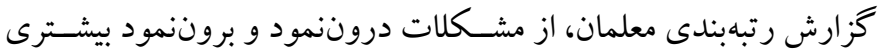

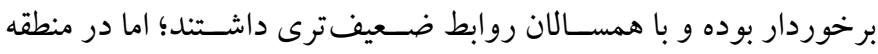
برخوردار، عكس اين موضوع صادق بود.

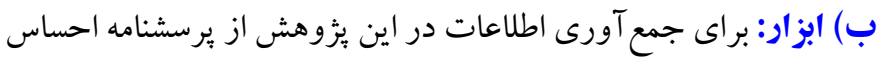

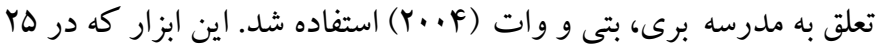

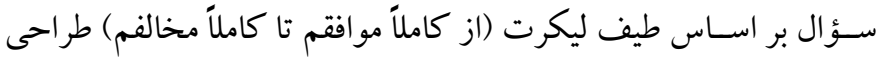

مهارتهاى اجتماعى-هيجانى دانش آموزان شــود، بسـيار حائز اهميت

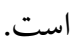

يُزوهش حاضـر با توجه به موضسوع و اهداف در نظر گر فته شـده، علاوه بر جنبه هاى كاربردى كه ذكر شــد از جنبه نظرى نيز داراى اهميت اســت. در اين راســتا اين مطالعه در بـى آن اســت كه در تكوين نظريه يادگيرى اجتماعى - هيجانى (با اسـتفاده از يزوهش هاى متمركز بر داخل كشور) تلاش كند، زيرا در ايران ضعف يُوهشهاى علمى در اين زمينه

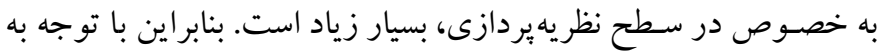

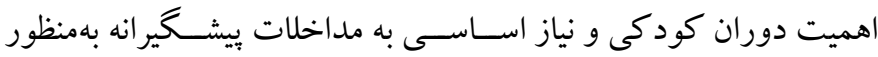

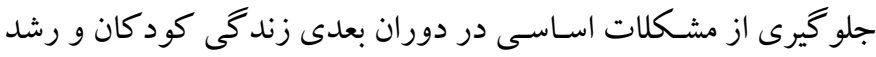
رفتارهاى تنظيم هيجان در آنها؛ كمبود يا عدم وجود يكك برنامه نظامدار

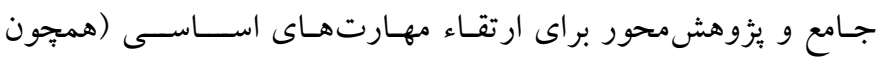

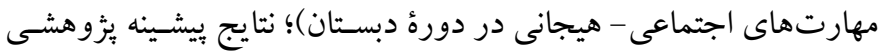

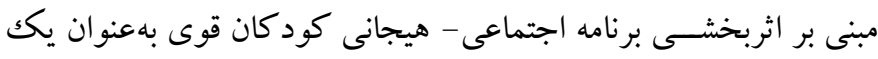
برنامه اميدبخش (با هدف بهبود احسـاس تعلق به مدرسه و توانمندسازى كودكى در مواجهـه بـا كشـاكشهـا)؛ و همجنين از آنجايى كـه برنامه اجتمـاعى - هيجانى كود كان قوى از ابتدا براى كود كان در معرض خطر

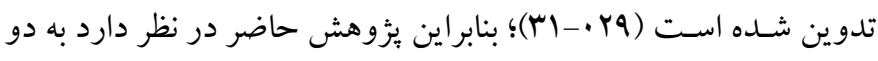

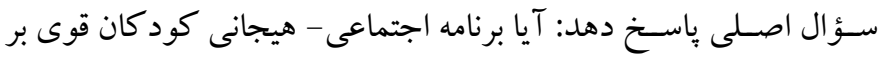

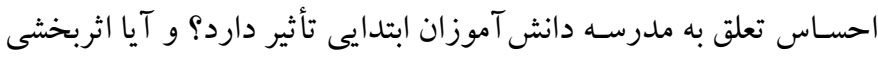
برنامه در مناطق محروم و برخوردار تفاوت معنادارى با هم دارند؟

روش ثز بزوهش الف) طرح هزوهش و شر كت كنند كان: در اين يزوهش براى دستيابى به اهداف يزٔوهش از روش نيمهآزمايشى و طرح مقايسه گروهوهاى نابرابر

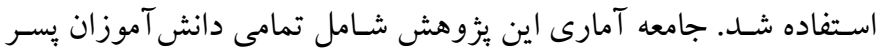

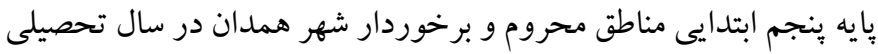
1T94_9V

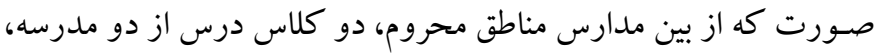
و از مناطق برخوردار نيز دو كلاس درس از دو مدرسـه بهطور تصـادفى انتخاب شــند و بهطور تصـادفى در هر منطقه، يكى از كلاس ها بهعنوان كروه گواه و يكك از كلاسها بهعنوان گروه آزمايش، نام كذارى شــدند. 
دانشـكاه علامه طباطبايى تأييد شــــ نتايج مربوط به روايى سـازه مقياس احساس تعلق با مدرسه با روش تحليل مؤلفه هاى اصلى وجود شش عامل

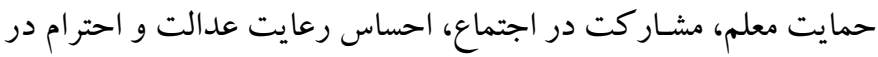
مدرسه، احساس مثبت نسبت به مدرسه، ارتباط فرد با مدرسه، و مشار كت ركت

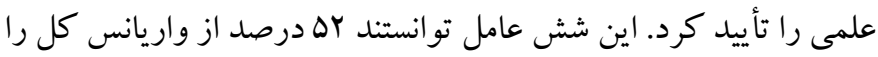

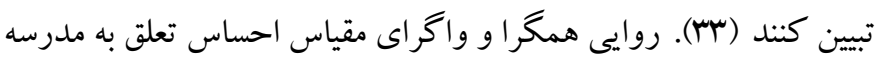

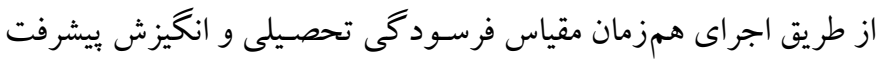

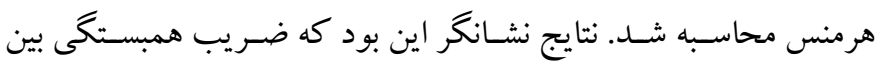

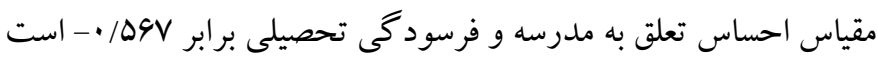

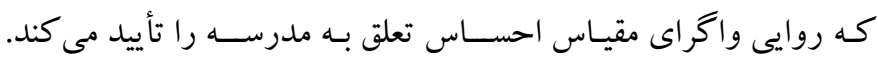

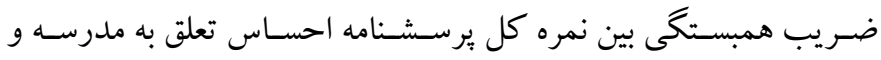

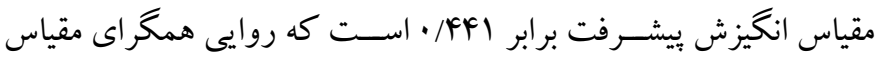
احساس تعلق به مدرسه را تأييد مى كند (سب).

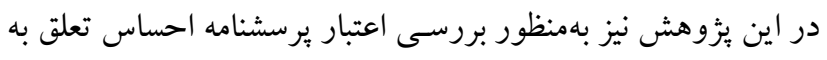

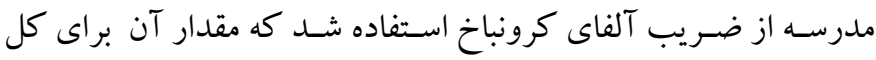
يرسشنامه MA/ • به دست آمد و براى مؤلفه هاى احساس تعلّق به همسالان

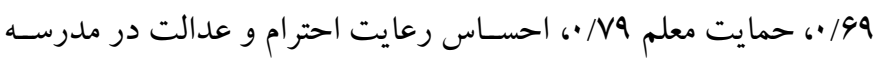

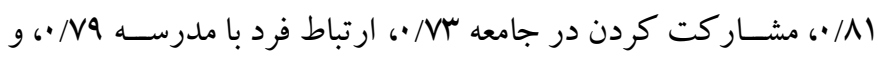
مشار كت علمى هA/ • به دست آمد. نظر شـامل r ا درس است كه طى با جلسـه •ه تا •ودقيقهاى (هر هفته

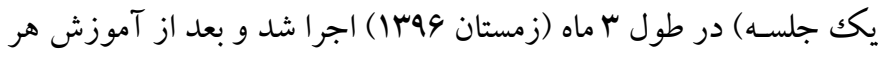

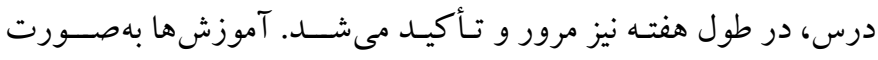

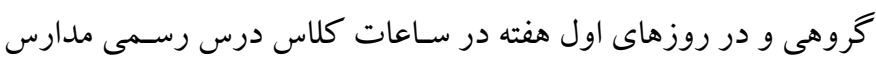

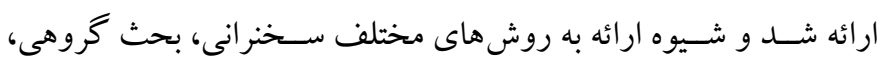
ايفاى نقش، و بِخش تصـاوير و كليٍ هاى مرتبط بود. در منطقه محروم برنامه مورد نظر توسط معلم كلاس درس اجرا شد، اما در منطقه برخوردار برنامه مورد نظر توسط معلمى ديخر (بيرون از مدرسـه) اجرا شد اما معلم كلاس نيز حضور داشت و در صورت لزوم در مواردى كه نياز به توضيح

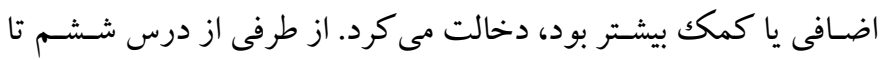
درس يـازدهم بـه دليـل زياد بودن حجم مطالب و طولانى بودن دروس و و

4. Engagement in the broader community

5. Relatedness of self with school

6. Academic engagement
شــده اسـت، داراى 9 خردهمقياس احسـاس تعلق به همسـالان'، حمايت

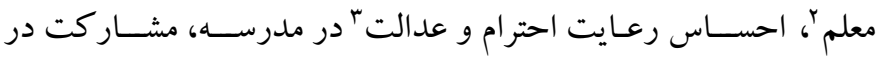

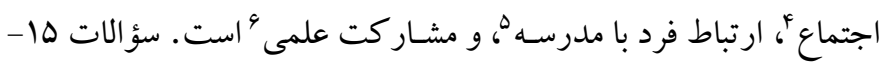

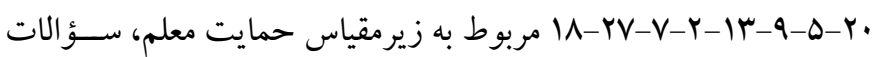

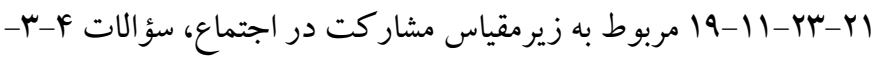

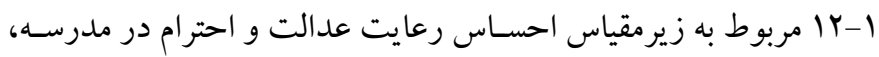

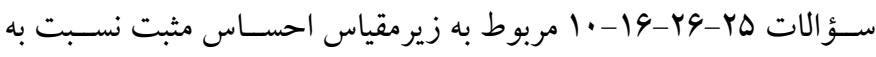

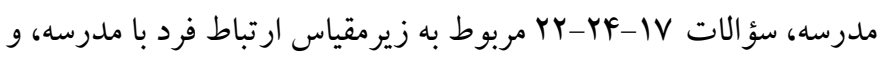

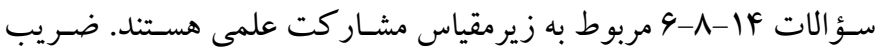

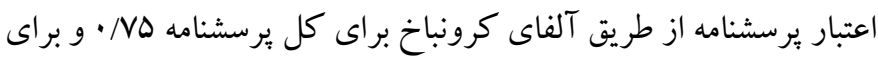

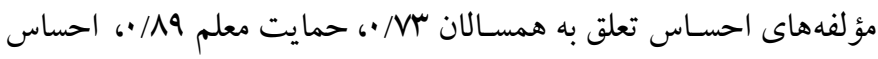

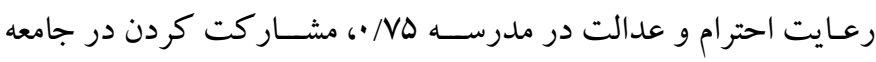

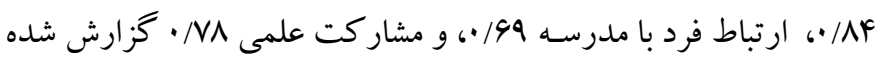

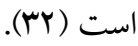

در ايران نيز مكيـان و كلانتر كوشــهـ به بررسـى روايى و ويايايى اين

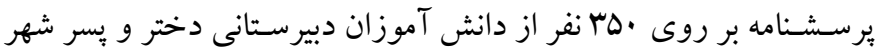

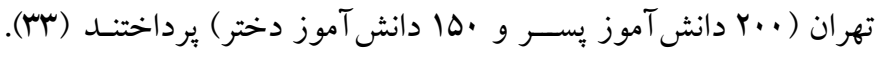

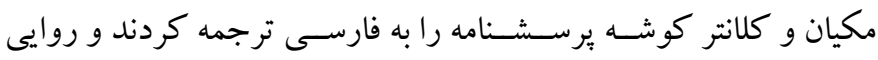
صورى آن توسط جند تن از استادان دانشكده روانشناسى و علوم تربيتى رئى

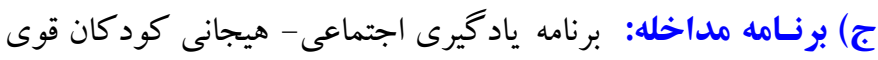

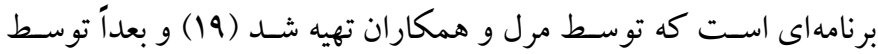

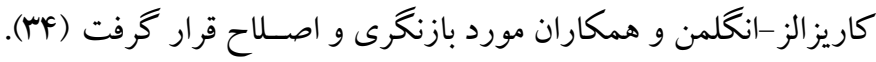

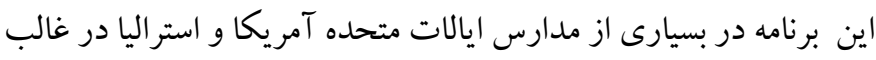

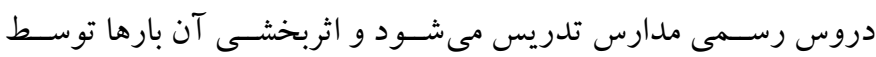

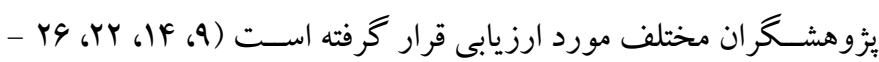
YN ) بعد از ترجمه كتاب به فارسـى و اعتبارســنجى برنامه و اطمينان از

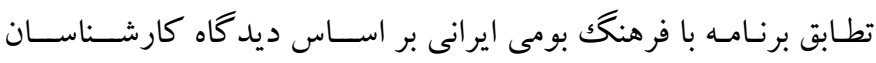

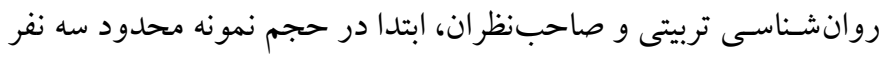

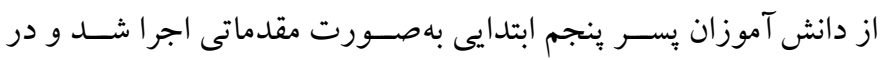

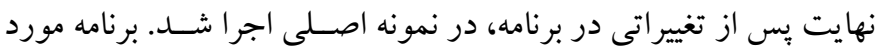

1. Students' Sense of Belonging With Peers

2. Teacher support

3. Fairness and safety 
هيجانى و اين برنامه آموزشى داشتند. هر دو گروه معلمان گزارش كردند

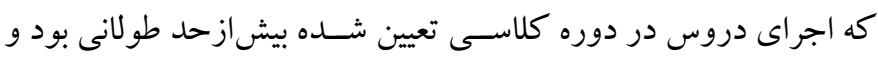

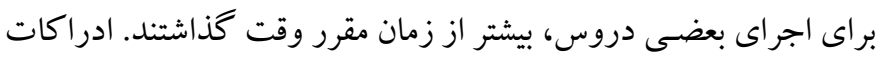

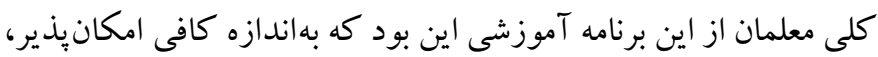

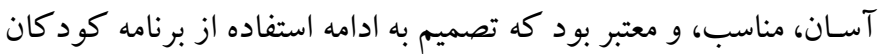
قوى در كلاسهاى درسى خود گرفتند. معلمان هر دو گروه، درباره اين موضوع كه بهتر است اين برنامه جزو دروس رسمى مدارس باشد، همنظر درد

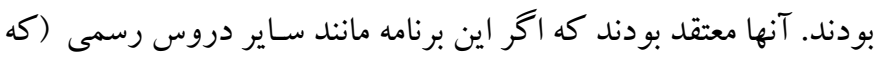
در مدارس اجرا مىشودن و در طول هفته، زمانى براى آنها در نظر گرفته آنه

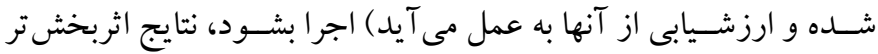

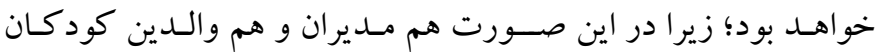

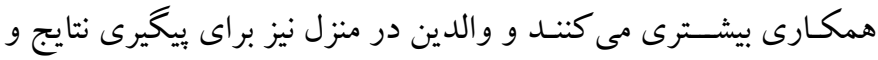

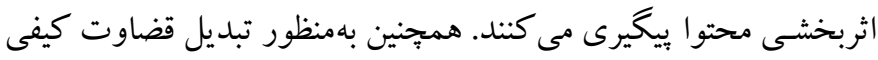

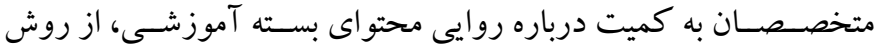
لاوشه' كه به ضريب روايى محتوايى نيز معروف است (4) استفاده شد. بهمنظور به دســت آوردن ضــريب روايى بسـته آموزشسى، از م نفر از

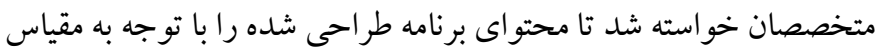

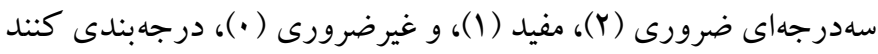
كه مقدار آن VD/· به دسـت آمد كه نشـان دهنده ضـريب محتواى بالا و مناسـب اسـت. در جدول ا اهداف و محتواى برنامه اجتماعى - هيجانى كود كان قوى به طور خلاصه ارائه شده است.
نداشـتن آمادگى بيشين دانش آموزان، ارائه دروس طى دو جلسه در هفته

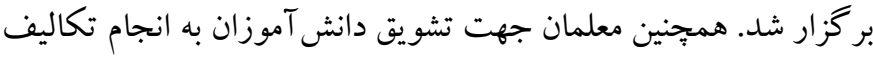

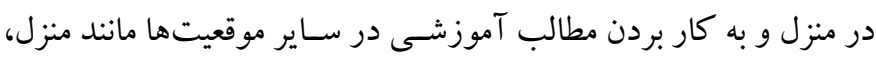

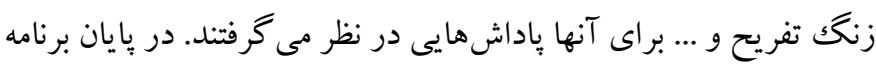
نيز از تمامى معلمان و دانش آموزان گروه آزمايش با هدايايى تقدير شد.

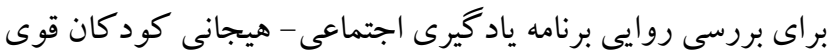

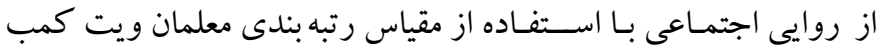

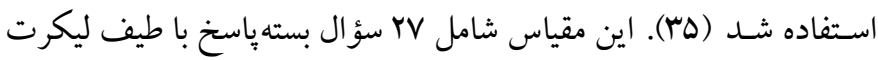

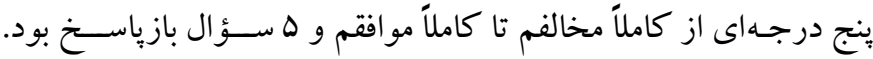
سؤالات در زمينه ضرورت آموزش برنامه اجتماعى - هيجانى در مدارس و امكانسنجى آن بود. سؤ الات بازياسخ عبارت بودند ازئ

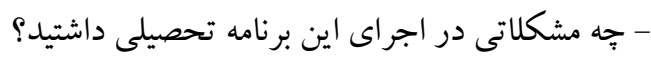
- آيا روش تدريس اين دروس را تغيير داديد؟ جِكونه؟ - جهه تغييراتى در محتواى اين برنامه تحصيلى ايجاد شد؟

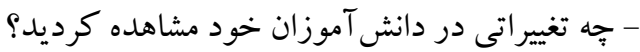
نتايج بررسـى روايى نشـان داد برنامه از روايى كافى برخوردار بوده

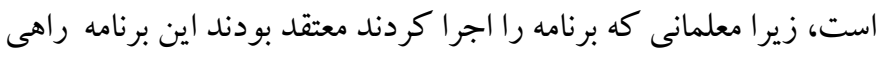

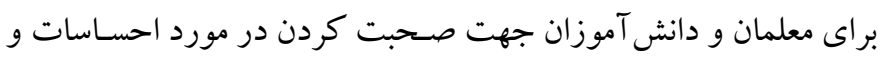
راهى براى دانش آموزان جهـت درخواســت كمكك ارائه كرد. همرجنين

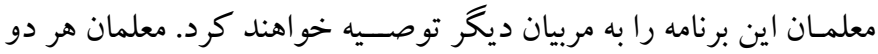

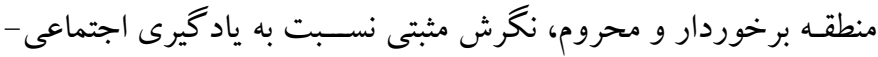

\section{جدول ا: اهداف و محتواى برنامه اجتماعى - هيجانى كود كان قوى}

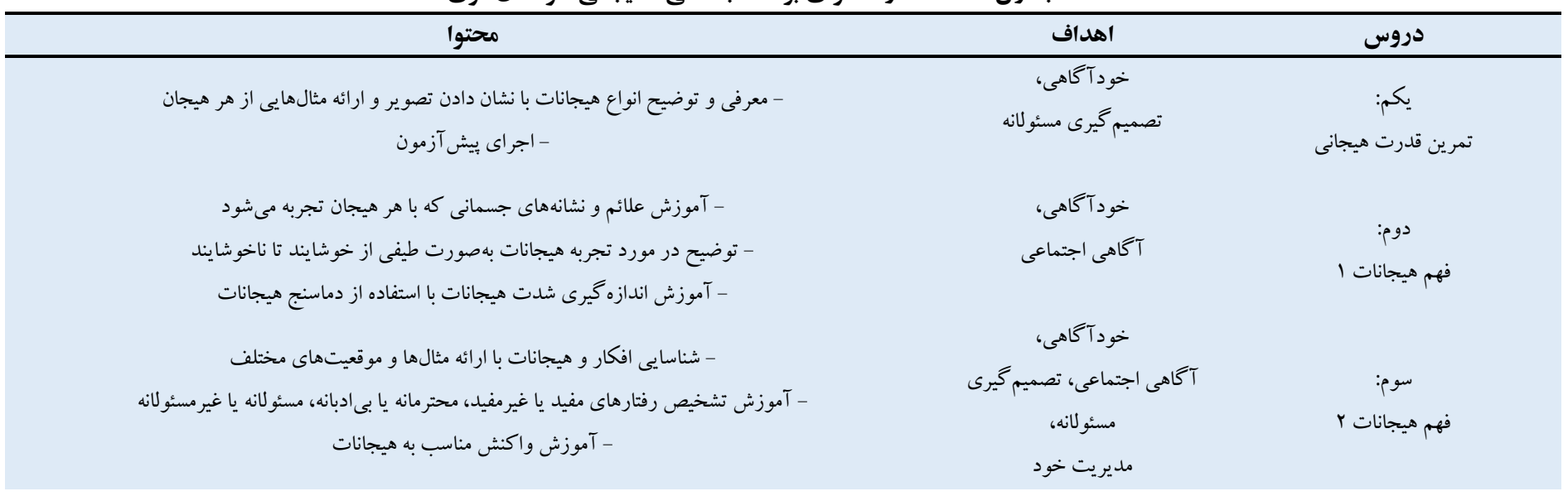

1. Lawshe 


$$
\begin{aligned}
& \text { - آموزش گوش دادن فعال و نمايش همدلى } \\
& \text { - آموزش شناسايى و مدلسازى هيجانات } \\
& \text { - آموزش حدس زدن هيجانات }
\end{aligned}
$$

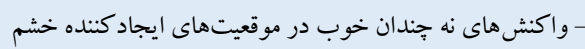

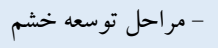

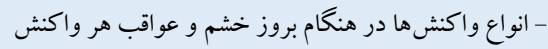

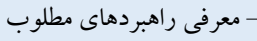

- شناسايى انواع تلههاى فكرى (خطاهاى شناختى)

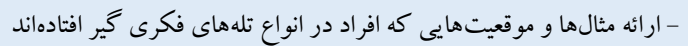

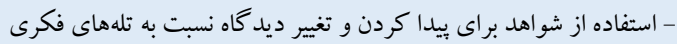

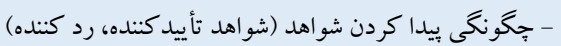

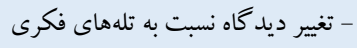

- حفظ نكرش مسئولانه و محترمانه حين منازعه - آموزش گوش دادن مشتاقانه

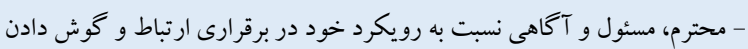

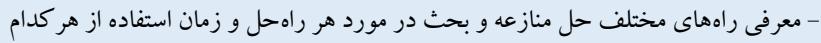

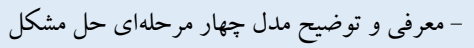

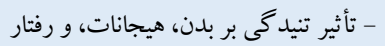

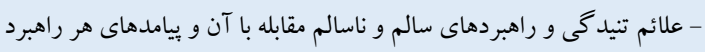

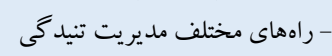

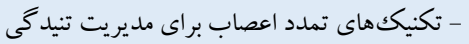

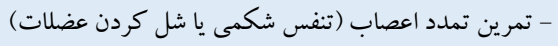

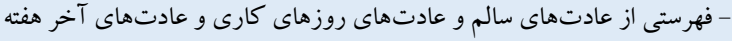

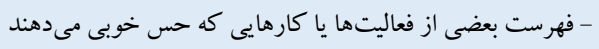

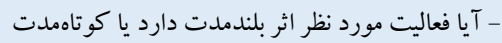

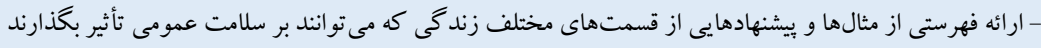

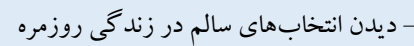

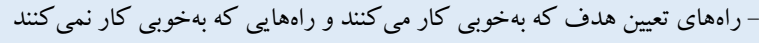

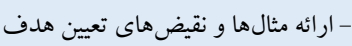

- تعيين اهداف خاص، قابل سنجش، قابل دستيابي، مر تبط و به جا (هوشمندانه)

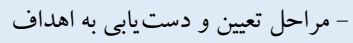

- ارائه مثالهايى از اهداف غيرهوشمندانه

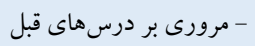

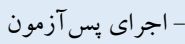

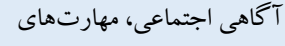

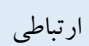

$$
\text { تصميم گيرى مسئولانه، }
$$

آكاهى اجتماعى، مهارتهاى (اريت

ينجم:

مقابله با خشم بنجم

ارتباطى

خود آكاهى،

مديريت خود

خود آكاهى،

مديريت خود،

آكاهى اجتماعى، تصميم گيرى

هفتم:

تفكر شفاف r

مسئولانه،

خود آكاهى،

مديريت خود،

آكاهى اجتماعى، تصميم گيرى

مسئولانه،

ششم: تفكر شفاف 1

مهارتهاى ارتباطى

$$
\text { تصميم خيريت خودئ مسئ، لمانه، }
$$

نهم:

رهايى از تنيدى

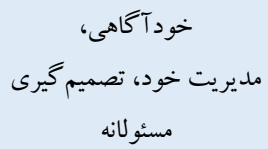

دهم:

مثبت زندكى كردن

$$
\text { مسئولانه }
$$

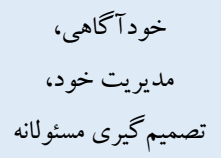

يازدهم:

ايجاد اهداف مستحكم و هوشمندانه

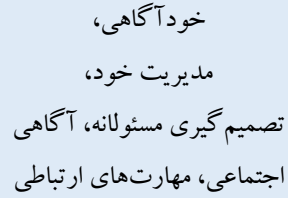

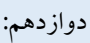

بإيان
نفر از استادان روانشناسى تربيتى و معلمان دوره ابتدايى نسبت به ارزيابى اثربخشى آن كمك گرفته شد. در اين راستا، يس از هماهنكى هاى للازم
د) روش اجرا: بعد از ترجمه و آماده شـدن كتاب يادگيرى اجتماعى -

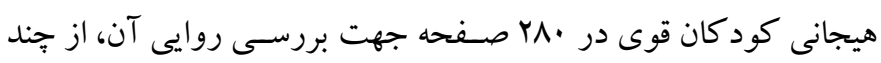


آن و محرمـانـه مـانـدن اطللاعـات، و اينكه هيج خطرى كود كان آنها را تهديد نمى كند، بهصسورت كتبى رضـايت خود را اعلام كردند. همجنين

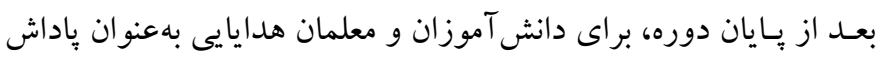

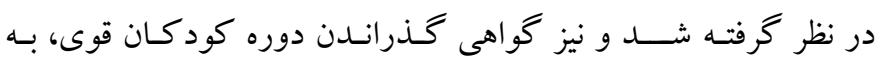

دانش آموزان داده شد.

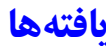

در جدول Y آمارههاى توصيفى احساس تعلق به مدرسه و مؤلفههاى آن

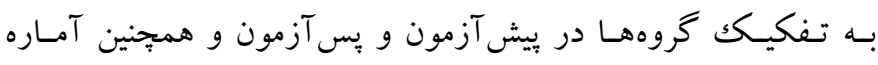
كالمو گروف-اسميرنف جهت بررسى نرمال بودن ارائه شده است.
با مسئولين آموزشويرورش استان همدان، از هر كدام از مناطق محروم و برخوردار دو مدرسـه پِسرانه بهصورت تصـادفى انتخاب شدند و بعد از

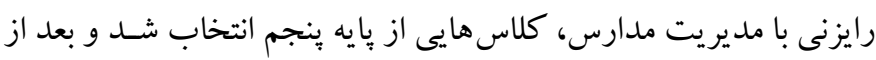

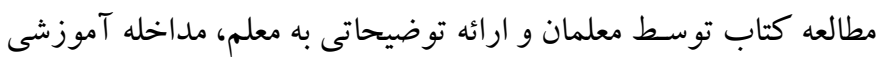

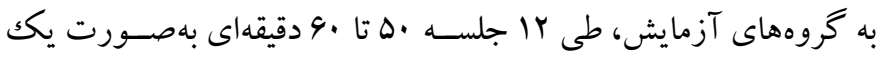

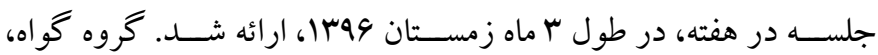

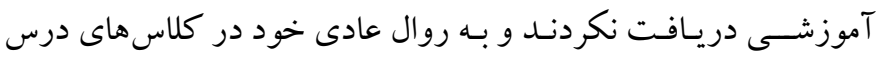

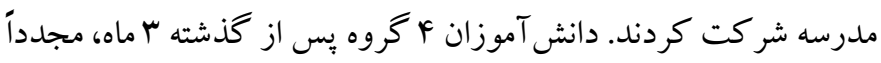

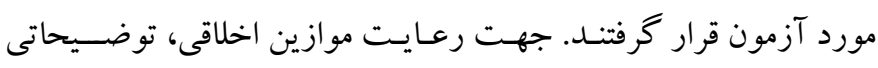
درباره برنامه مذكور به والدين داده شــــ و آنها بعد از اطمينان از مز اياى

جدول ז: ميانكين، انحراف معيار و آماره كالمونتروف-اسميرنف متغير احساس تعلق به مدرسه و مؤلفههاى آن

\begin{tabular}{|c|c|c|c|c|c|c|c|}
\hline \multirow[b]{2}{*}{ سطح معنادارى } & \multirow{2}{*}{ آماره كالمونكروف-اسميرنف كل } & \multicolumn{2}{|c|}{ كروه كنترل } & \multicolumn{2}{|c|}{ كروه آزمايش } & \multirow{2}{*}{ زمان } & \multirow{2}{*}{ متغير } \\
\hline & & انحر اف معيار & ميانغين & انحر اف معيار & ميانغين & & \\
\hline .119 & $1 / 1 F$ & .191 & r/r & $\cdot / 4 \wedge$ & Y/VD & يبش آزمون & \multirow{2}{*}{ حمايت معلم } \\
\hline$\cdot / 10$ & $1 / 1 r$ & $\cdot / \Delta$ & $r / r q$ & $\cdot / 4 F$ & r/r & يس آزمون & \\
\hline$\cdot /$ & $\cdot / 91$ &.$/ 91$ & Y/AY & $\cdot / M$ & $r / 9 r$ & ي يش آزمون & \multirow{2}{*}{ مشار كت در اجتماع } \\
\hline$\cdot / \mu$ & $1 / \cdot 9$ & $\cdot / \Delta 1$ & $r / \cdot r$ &.$/ 90$ & Y/Q1 & ي يس آزمون & \\
\hline$\cdot / \cdot \wedge$ & $\cdot / r \Delta$ & $\cdot / \Lambda \Delta$ & r & • & $r / 11$ & ي ييش آزمون & رعايت عدالت و احترام در \\
\hline$\cdot / \cdot V$ & $\cdot / r$. & .191 & r/rA & $\cdot / \Delta V$ & $r / F \Delta$ & 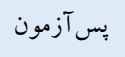 & مدرسه \\
\hline$\cdot / 11$ & $1 / \cdot 1$ & .190 & $r / r \Delta$ & $\cdot / 49$ & $r / \Delta r$ & ي ي & \multirow{2}{*}{ احساس مثبت به مدرسه } \\
\hline 每 & $1 / N r$ & $\cdot / \Delta r$ & $r / r q$ & $\cdot / 41$ & $r / 19$ & ي يس آزمون & \\
\hline$\cdot / r r$ & $1 / r \pi$ & .191 & $r / \cdot r$ &.$/ 01$ & $r / 99$ & ي يش آزمون & \multirow{2}{*}{ ارتباط با مدرسه } \\
\hline$\cdot / k \pi$ & $1 / \Delta 1$ & $\cdot / \Delta 9$ & r/M & $\cdot / 4 \Lambda$ & $r / F F$ & يس آزمون & \\
\hline$\cdot / r \mid$ & $1 / 19$ & $\cdot / 91$ & r/AY & .194 & $r / \Delta \Lambda$ & ي يش آزمون & \multirow{2}{*}{ مشار كت علمى } \\
\hline$\cdot / F r$ & $1 / \Delta r$ & $\cdot / \Delta r$ & r/rq & $\cdot / A q$ & $r / \Delta$. & يس آزمون & \\
\hline$\cdot / \Delta r$ & $\cdot / \wedge$ & .190 & $r / .9$ & $\cdot / 49$ & $r / \Delta \Delta$ & ي بيش آزمون & احساس تعلق به مدرسه (نمره \\
\hline 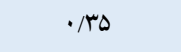 & . /9 & $\cdot / 4 \Delta$ & $r / r V$ & $\cdot / 49$ & r/Mr & پֶس آزمون & كل) \\
\hline
\end{tabular}

به دليل رعايت بيش فرضهاى اســــى تحليل كوواريانس از جمله

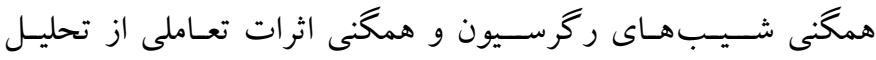

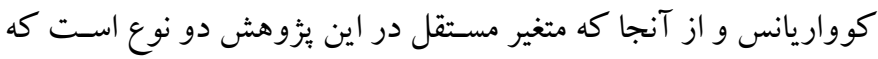

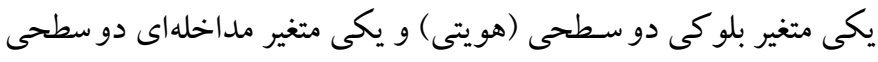

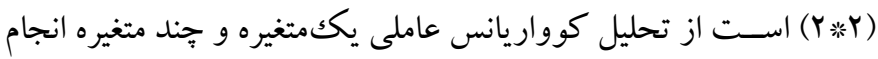
شـــ نتايج آزمون امباكس نشـان داد، ماتريس واريانس -كوواريانس در كروههاى مورد مطالعه همخن اسـت (P> (P>
مندرجات جدول Y نشان مىدهد كه ميانگين نمرات بِ بـ آزمون متغير

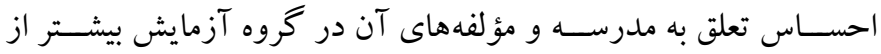

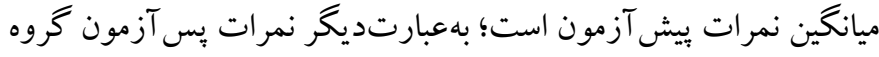
آزمايش نسـبت به بيش آزمون افزايش يافته اسـتـ. همجنين نتايج آماره

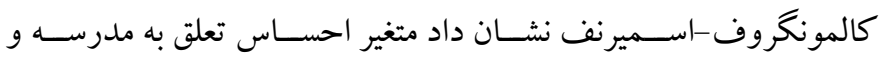
مؤلفه هاى آن داراى توزيع نرمال هستند. 
فوق در شـرايط مختلف مقايسه در مناطق آموزشى (محروم و برخوردار)"

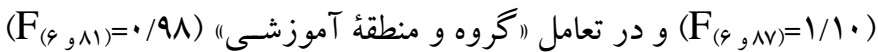

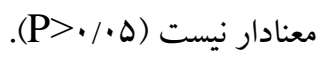

جهت بررسـى اين نكته كه آيا آموزش برنامه اجتماعى- هيجانى

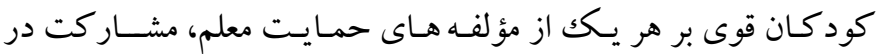

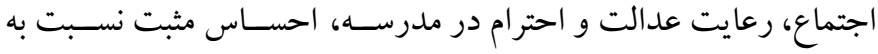

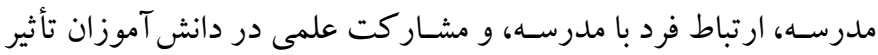
معنادارى دارد يا نه از تحليل كوواريانس يككمتغيره استفاده شد كه نتايج

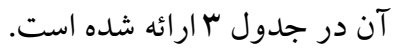

نتايج آزمون لون نيز در همه مؤلفه هاى احسـاس تعلق به مدرسه حاكى از

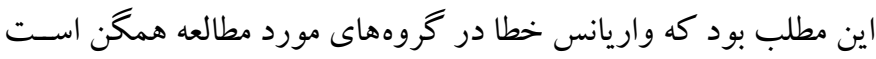

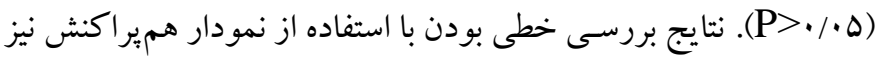

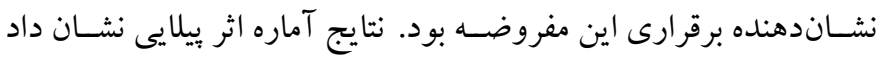

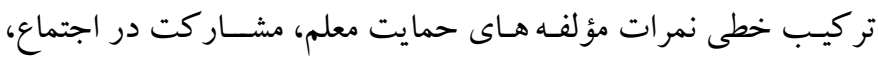
رعايت عدالت و احترام در مدرسـه، احسـاس مثبت نسـبت به مدرسهـه، ارتباط فرد با مدرسه، و مشار كت علمى در گروههاى "آزمايش و كو اهنه

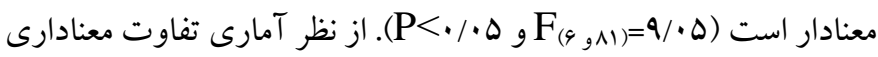
در متغيرهاى وابسته تركيبى نمرات مؤ لفههاى احساس تعلق به مدرسه بين

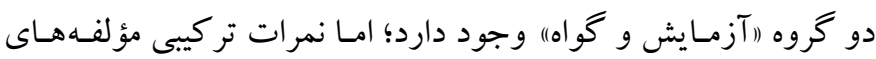

جدول با: نتايج تحليل كوواريانس يككمتنيره جهت مقايسه نمرات مؤلفههاى احساس تعلق به مدرسه در دو كروه هآزمايش و كواهي

\begin{tabular}{|c|c|c|c|c|c|c|c|c|}
\hline توان & ضريب اتا & سطح معنادارى & $\mathbf{F}$ & ميانكين مجذورات & درجه آزادى & مجموع مجذورات & منابع تغيير & متغير \\
\hline \multirow{2}{*}{ - /AF } & $\cdot / V^{f}$ & $\cdot / \cdots r$ & N/9Y & $1 / \& \Delta$ & 1 & $1 / F \Delta$ & 0 & \multirow{2}{*}{ حمايت معلم } \\
\hline & & & & .119 & 19 & $\mid r / 91$ & خطا & \\
\hline \multirow{3}{*}{./91 } & $\cdot /$ /4 & $\cdot \ldots$ & $19 / 9 \mathrm{~V}$ & $1.1 \% 9$ & 1 & $1 . / 49$ & خروه اه & \multirow{2}{*}{ مشار كت در اجتماع } \\
\hline & & & & .194 & 19 & $\Delta r / 4 q$ & 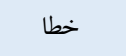 & \\
\hline & .149 & $\cdot \ldots$ & $r Q / F F$ & V/Ar & 1 & V/Ar & 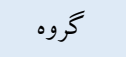 & رعايت عدالت و \\
\hline.$/ 99$ & & & & $\cdot / T V$ & $\wedge 9$ & Yr/AG & خطا & احترام در مدرسه \\
\hline \multirow{2}{*}{.$/ 91$} & . &.$/ .1$ & $11 / \pi T$ & $r / 90$ & 1 & $r / 90$ & 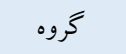 & احساس مثبت نسبت \\
\hline & & & & $\cdot \pi r$ & $\wedge 9$ & $r V / V F$ & خطا & به مدرسه \\
\hline \multirow{2}{*}{$\cdot / \Delta \Lambda$} &.$/ \Delta r$ & $.1 . \pi r$ & F/NY & $1 / \cdot 9$ & 1 & $1 / .9$ & كروه اه & \multirow{2}{*}{ ارتباط با مدرسه } \\
\hline & & & & Tr & 19 & 19/99 & خطا & \\
\hline \multirow{2}{*}{.$/ 91$} &.$/ \mu \mu$ &.$/ .1$ & $11 / \pi$ & $r / T 1$ & 1 & $r / r \mid$ & 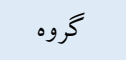 & \multirow{2}{*}{ مشار كت علمى } \\
\hline & & & & $\cdot / r$ & $\wedge 9$ & $|V / \Delta|$ & خطا & \\
\hline \multirow{2}{*}{.$/ 91$} & \multirow{2}{*}{$\cdot / 4 q$} & \multirow{2}{*}{$\cdot \cdots$} & \multirow{2}{*}{$\Delta \cdot / \wedge q$} & F/NG & 1 & F/Vq & 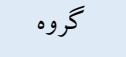 & احساس تعلق به \\
\hline & & & & .1 .9 & 91 & $N / \Delta)$ & خطا & مدرسه \\
\hline
\end{tabular}

درصـد از تغييرات احساس مثبت نسبت به مدرسه، كاه درصد از تغييرات

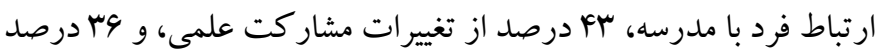
از تغييرات احساس تعلق به مدرسه را تعيين كند.

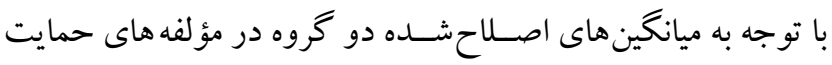

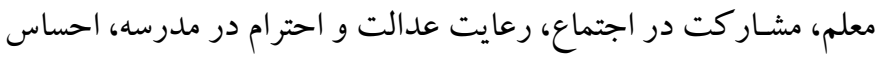
مثبت نسبت به مدرسـه، ارتباط فرد با مدرسه، و مشار كت علمى معى توان

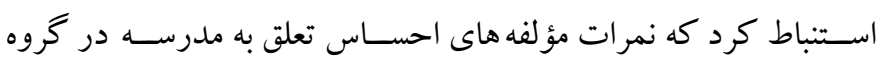

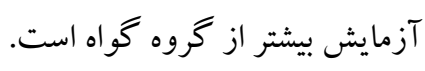

نتايج مندرج در جدول ب نشـان مىدهد كه آموزش برنامه اجتماعى -

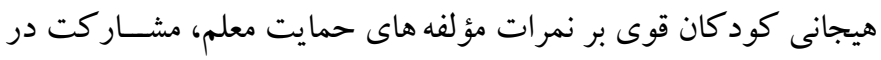
اجتماع، رعايت عدالت و احترام در مدرسـه، احسـاس مثبت نسـبت به

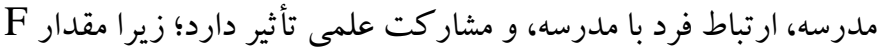

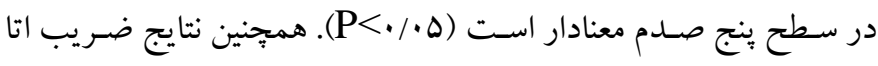

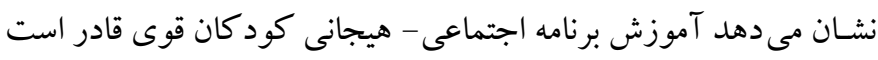
لد VF

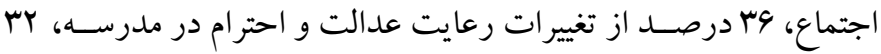


دانش آموزان ابتدايى يايه ينجم و شـشـم تأثير دارد ( • (). فاير كلات وهام

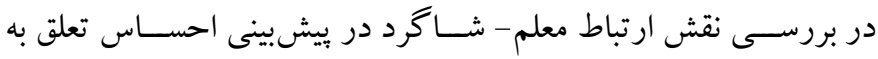

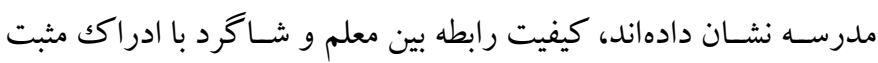

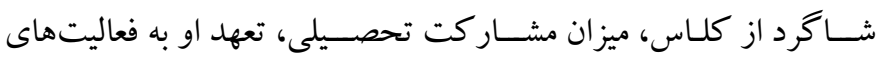

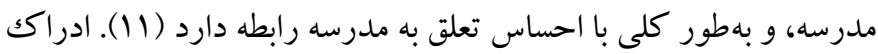

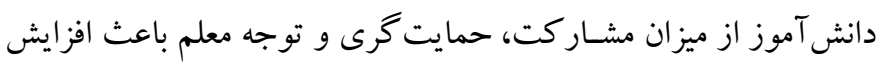

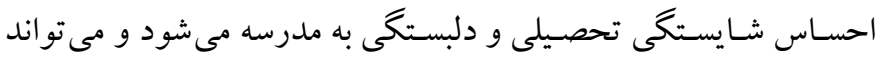
ييش بينى كننده قوى براى ييوند دانش آموز با مدرسه باشد.

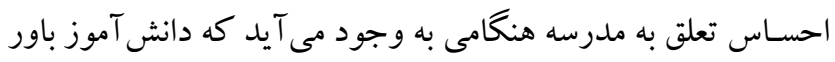

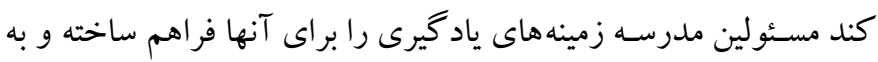

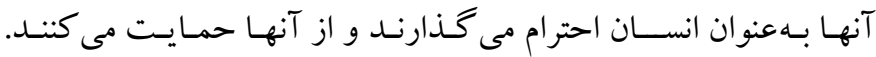
دانش آموزان در محيط مدرسه وقتى مشاهده مى كنند كه كار كنان مدرسه

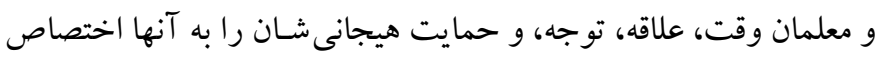

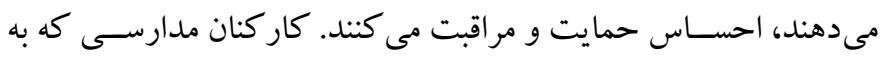

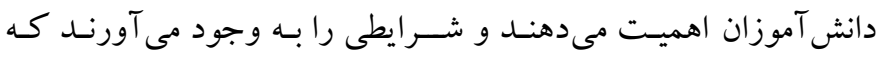
دانش آموزان از لحاظ هيجانى، اجتماعى، روانى و تحصسيلى رشـــ كنيد؛

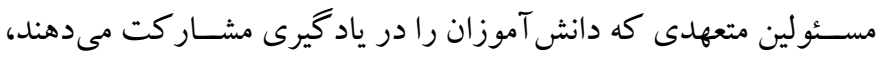

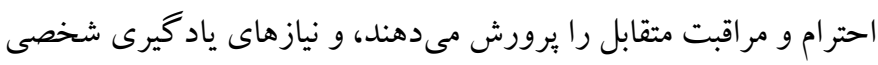

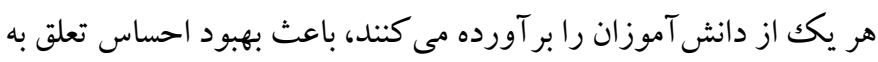
مدرسه در دانش آموزان خوا هند شد. هالت در يكك يُوهش تأثير راهنمايى و مشـاوره دانش آموزان توسط كار كنان مدرسه را بر احساس تعلق به مدرسه و مشار كت تحصيلى مورد

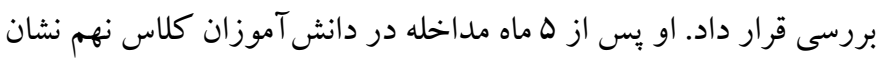

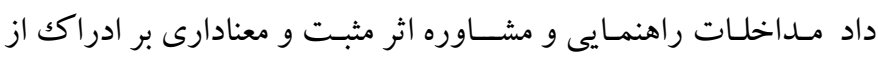

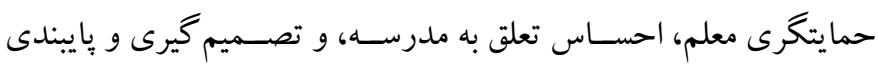
دانش آموزان به نظم مدرسـه دارد (r) (I). سـلهاف در مطالعهاى نشـان داد

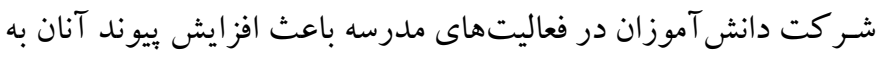

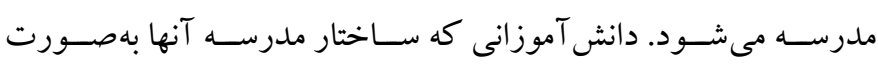

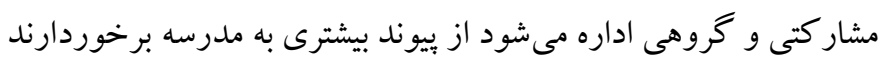

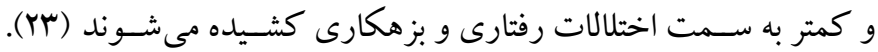
اهميت عضـويت در كروه در كارهاى ديويى نيز مشـاهده مىشـود. اين فيلسـوف معتقد اسـت تعليم و تربيت يكك فرايند اجتماعى اسـت نه يكك
بـا توجـهـ بـهـ اينكـهـ آموزش يـاد كيرى اجتمـاعى-هيجانى در تركيب خطى نمرات مؤلفـه هاى احســاس تعلق به مدرســه در منطقه (امحروم و

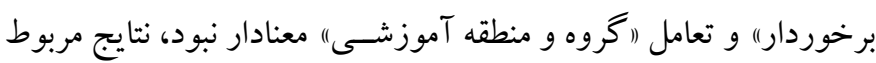

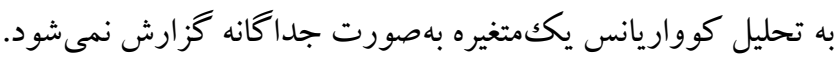
بحث و نتيجه كيرى هدف از انجام اين بثزوهش ارزيابى اثربخشسى برنامه ياد كيرى اجتماعى -

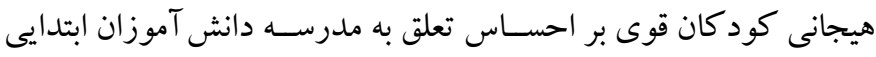

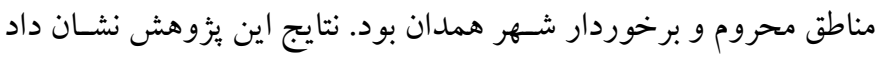

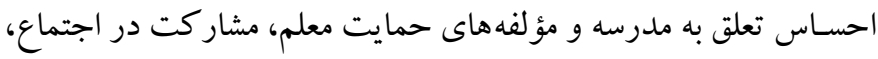
رعايت عدالت و احترام در مدرسـه، احســاس مثبت نسـبت به مدرسـه،

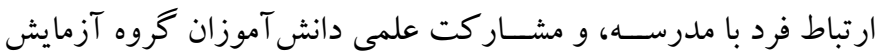
بيشتر از احساس تعلق به مدرسه دانش آموزان گروه گُواه است. همجنين نتـايج نشـان داد احســاس تعلق بـه مدرســه و مؤلفه هاى حمايت معلم، مشار كت در اجتماع، رعايت عدالت و احترام در مدرسه، احساس مثبت نسبت به مدرسـه، ارتباط فرد با مدرسـه، و مشار كت علمى دانش آموزان منطقه محروم و منطقه برخوردار به يكك ميز ان اسـت. همجنين نتايج نشان

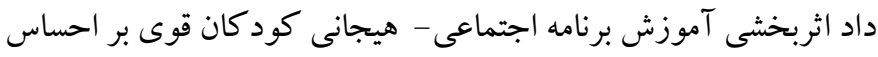

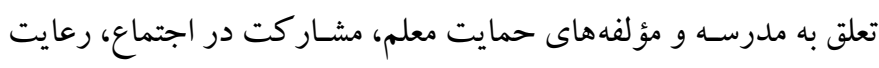

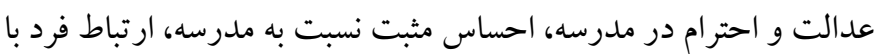
مدرسه، و مشار كت علمى در دانش آموزان منطقه محروم و دانش آموزان

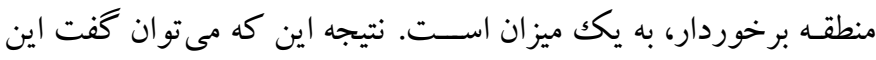
برنامه بر ایى دانش آموزان هر دو منطقه آموزشى مؤثر است.

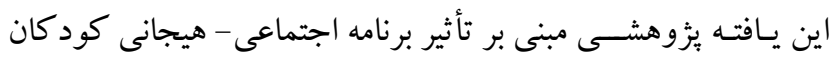

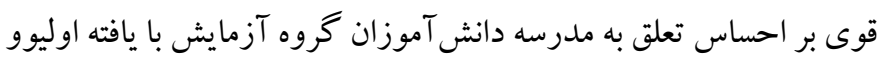

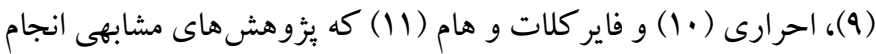

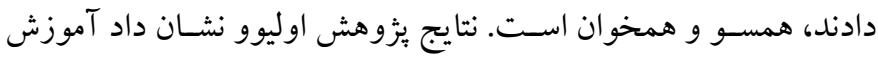

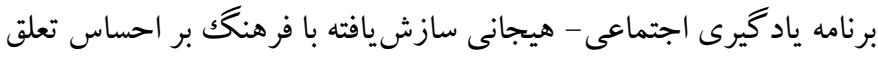

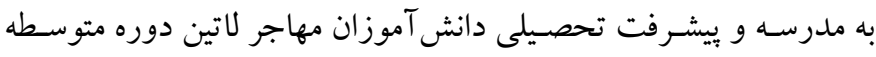

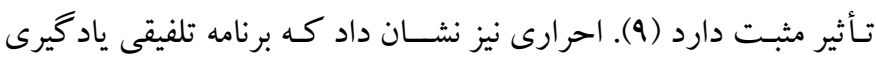

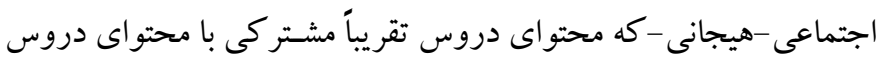

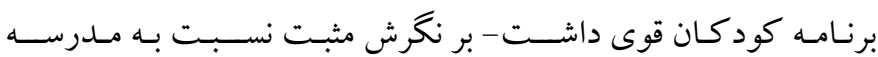


يافتها تأثير معنادار آموزش مهارتهاى اجتماعى-هيجانى را در هر دو

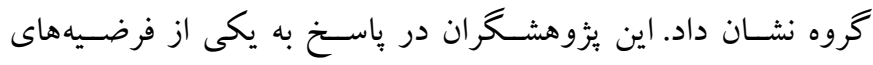

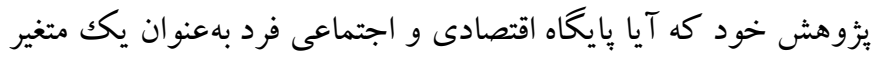

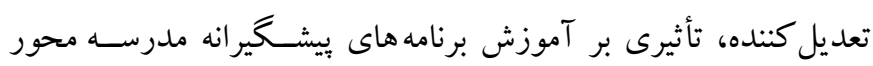

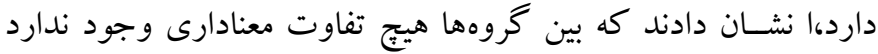

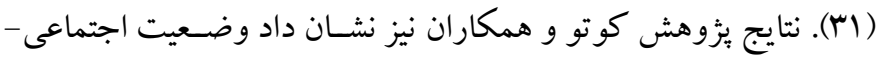

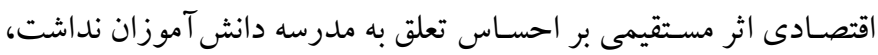

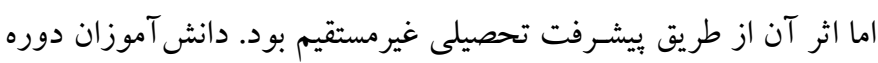
متوسـطه روسـتايى حس تعلق بيشـترى نسـبت به همتايان شـهرى خود

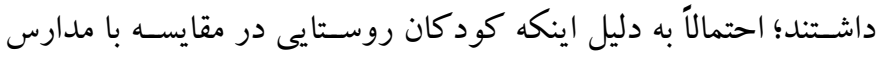

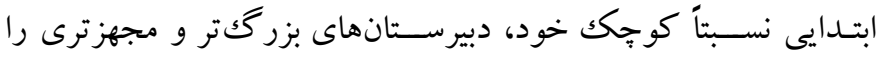

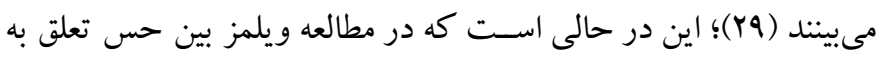
مدرسـه و وضعيت اجتماعى -اقتصادى ارتباط مثبتى وجود داشت (·r). همجنين فـاير كلات و هام مشــاهده كردند كه حس تعلق مدرســه در

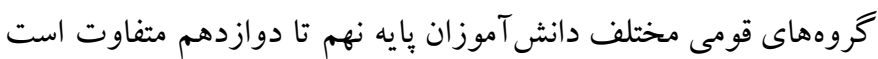
(11). و بـالـاخره بيتون و همكـاران در مطـالعه فراتحليلى دريـافنتـد كـه مداخلات اجتماعى - هيجانى بر نكرش نسبت به خود و ديخران و نبخرش

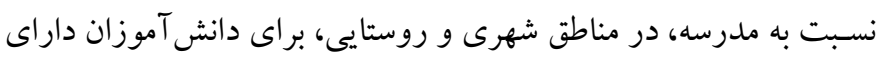
تنوع نزادى و قومى و با همه طبقات اقتصادى - اجتماعى تأثير دارد (19).

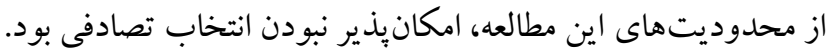

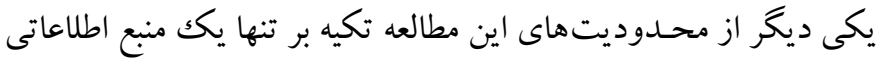

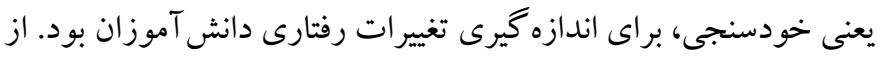

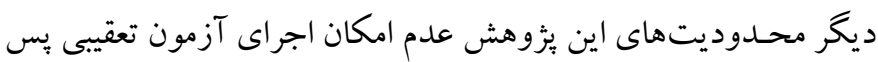

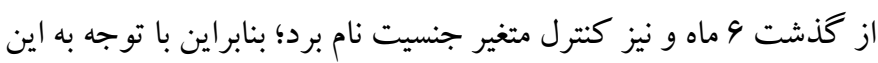
محدوديت ها ييشـنهاد مى شـود كه در يزوهش هاى آتى متغيرهاى كنترل

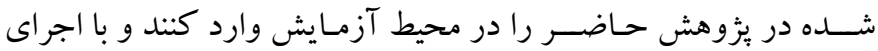

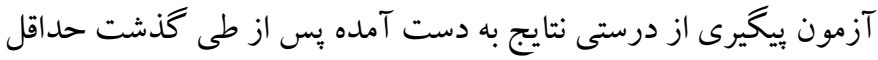

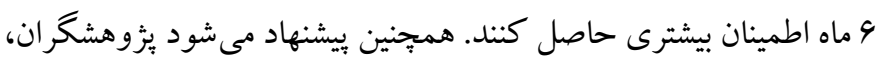
مطالعه را در شـر ايط انتخاب و انتساب تصادفى آزمودنى ها انجام دهند و براى جمع آورى دادههـا، از جنــد روش از جملـه مشــاهده، مصــاحبه با

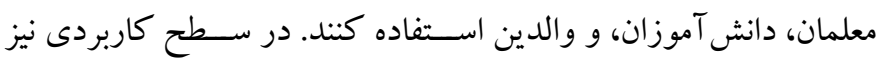

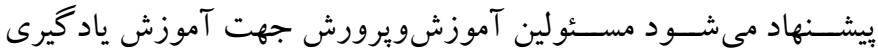

فر ايند خصـوصسى و دانش آموزان بايد در گروههاى اجتماعى فعاليت كنــــ. بـايــــ توجـه داشــت كه مقدار زمان مشـــار كت دانش آموزان در

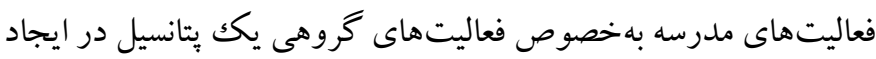

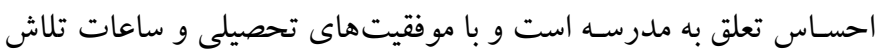
تحصيلى يعنى مشار كت تحصـيلى دانش آموزان رابطه مثبت دارد (11).

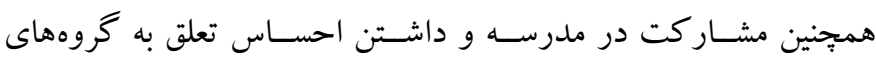

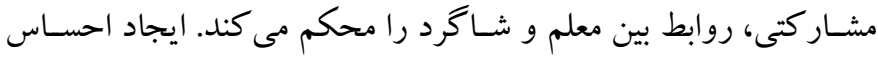

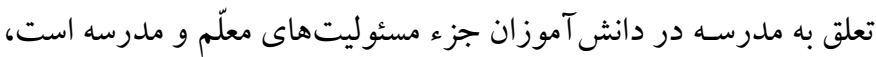

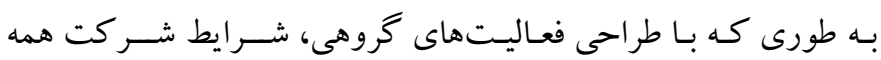

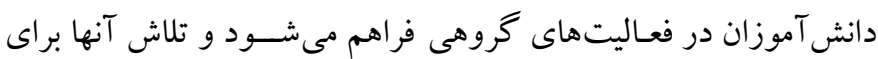

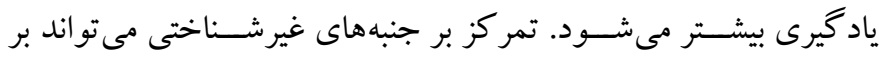

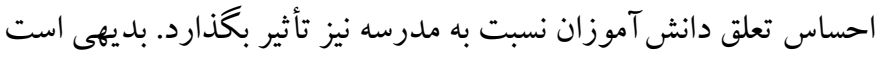

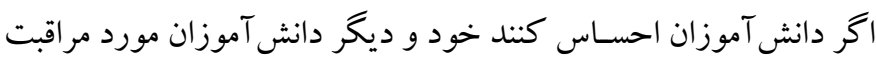
و حمايت از طرف مدرسـه هسـتند ييشـفت تحصسيلى بالاتر و رفتارهاى يرخطر كمترى خواهند داشت.

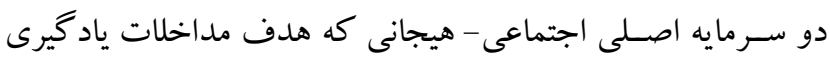

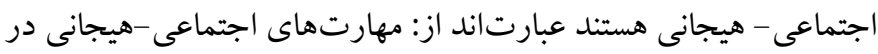

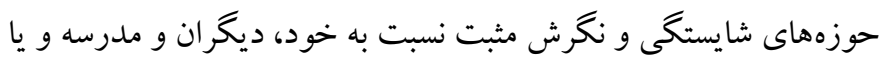

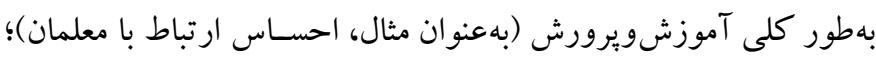
بنابراين انتظار مىرود كه ترويج مؤثر اين سرمايههاى اجتماعى-هيجانى

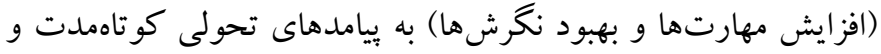

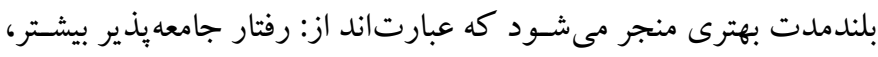

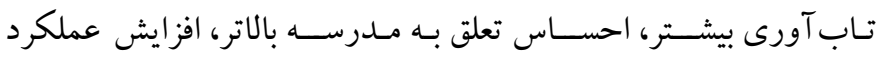

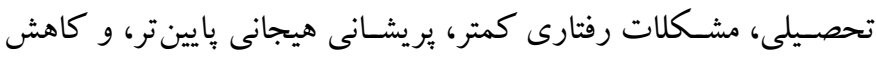

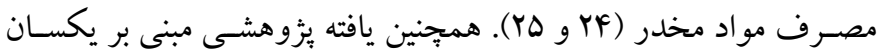

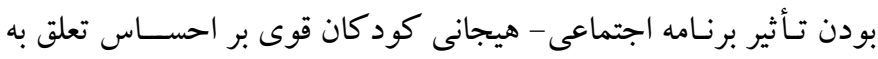

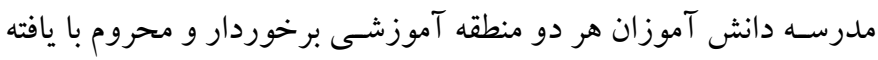

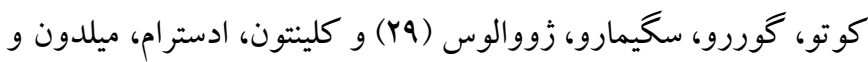
دويلا ( اسب) همسو و همخوان؛ و با يافتهاى فاير كلات و هام (11) و و ويلمز

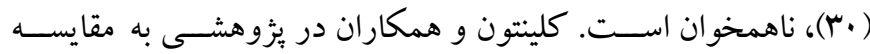
آكَاهى هاى اجتماعى-هيجانى بر مهارتهاى فردى دو گروه از افراد

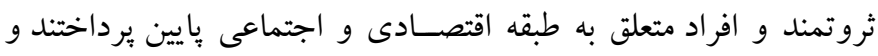




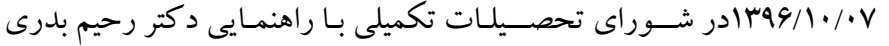

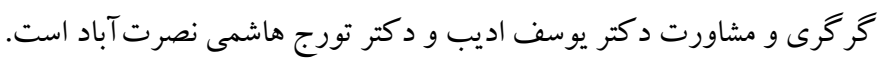

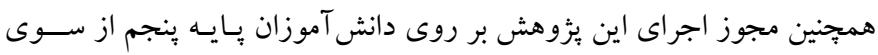

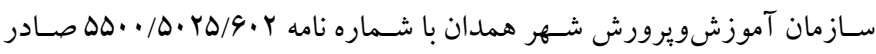
شـده اسـت. بدين وسـيله از اسـتادان راهنما و مشـاور، معلمان، مديران مدارس،

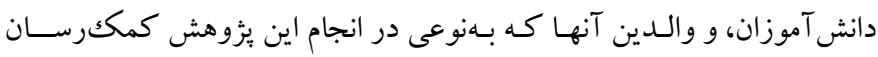
بودند، صميمانه سباسگز ارى مىشود. تضــاد منافع: اين يزوهش براى نويسـند كان هيج كونه تضـاد منافعى نداشــه

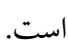

اجتمـاعى - هيجـانى در مــارس، اقـدامـاتى از جمله تلفيق آن در برنامه

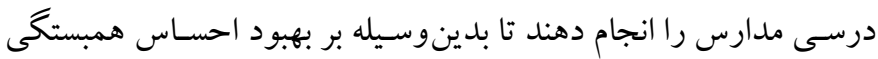

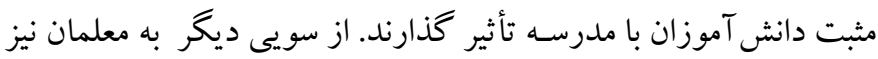

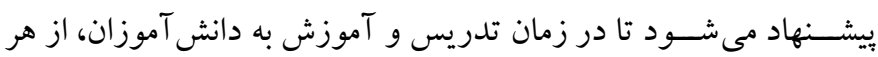
فرصتى جهت انتقال يادگيرى اجتماعى - هيجانى به دانش آموزان استفاده كنיد. تشـكر و قدردانى: اين مقاله برگر فته از رسـاله دوره دكتراى روانشـناسـى

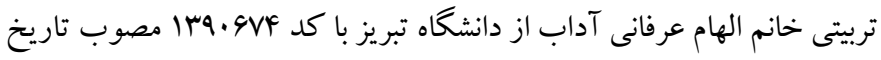




\section{References}

1. Kurniawan IN, Dewi WAK. Emotional awareness and school connectedness: a preliminary study among students in Indonesia. Procedia Soc Behav Sci. 2016; 217: 622-625. [Link]

2. Hakimzadeh R, Abolghasemi M, Nejati F. Comparing school connectedness, academic motivation and academic achievement between smart school students and traditional school students in Esfahan. Journal of Educational Scinces. 2012; 19(1): 151-170. [Persian]. [Link]

3. Yuen M, Lau PSY, Lee QAY, Gysbers NC, Chan RMC, Fong RW, et al. Factors influencing school connectedness: Chinese adolescents' perspectives. Asia Pacific Educ Rev. 2012; 13(1): 55-63. [Link]

4. Ito A. Enhancing school connectedness in Japan: The role of homeroom teachers in establishing a positive classroom climate. Asian Journal of Counselling. 2011; 18(1): 41-62. [Link]

5. Juvonen J. Sense of belonging, social bonds, and school functioning. In: Alexander PA, Winne PH, editor. Handbook of educational psychology. Mahwah, NJ, US: Lawrence Erlbaum Associates Publishers; 2006, pp: 655-74. [Link]

6. Cueto S, Guerrero G, Sugimaru S, Zevallos AM. Sense of belonging and transition to high schools in Peru. Int J Educ Dev. 2010; 30(3): 277-287. [Link]

7. Shochet IM, Dadds MR, Ham D, Montague R. School connectedness is an underemphasized parameter in adolescent mental health: results of a community prediction study. J Clin Child Adolesc Psychol. 2006; 35(2): 170-179. [Link]

8. Chapman RL, Buckley L, Sheehan MC, Shochet IM, Romaniuk M. The impact of school connectedness on violent behavior, transport risk-taking behavior, and associated injuries in adolescence. J Sch Psychol. 2011; 49(4): 399-410. [Link]

9. Olivo SMC. The effects of a culturally-adapted socialemotional learning curriculum on social-emotional and academic outcomes of Latino immigrant high school students [PhD Thesis]. [Oregon, United States]: College of Education and the Graduate School, University of Oregon; 2007, p: 54. [Link]

10. Ahrari G. The effectiveness of social-emotional learning curriculum on social-emotional competence [PhD Thesis]. [Tabriz, Iran]: Faculty of Education and Psychology, Tabriz University; 2018. [Persian].
11. Faircloth BS, Hamm JV. Sense of belonging among high school students representing 4 ethnic groups. J Youth Adolescence. 2005; 34(4): 293-309. [Link]

12. Holt KD. Bowling together or bowling alone: continuation high school students tell their stories [PhD Thesis]. [California, United States]: University of California, San Diego California State University, San Marco; 2008, pp: 1-129. [Link]

13. Collie RJ, Shapka JD, Perry NE. School climate and social-emotional learning: predicting teacher stress, job satisfaction, and teaching efficacy. Journal of educational psychology. 2012; 104(4): 1189-1204. [Link]

14. Taylor RD, Oberle E, Durlak JA, Weissberg RP. Promoting positive youth development through school-based social and emotional learning interventions: a meta-analysis off follow-up effects. Child Dev. 2017; 88(4): 1156-1171. [Link]

15. Kramer TJ. Evaluating a social and emotional learning curriculum, strong kids, implemented schoolwide. [PhD Thesis]. [Utah, United States]: Department of Counseling Psychology and Special Education, Brigham Young University; 2013, pp: 4849. [Link]

16. Payton J, Weissberg RP, Durlak JA, Dymnicki AB, Taylor RD, Schellinger KB, et al. The positive impact of social and emotional learning for kindergarten to eighth-grade students: findings from three scientific reviews. Technical report. Collaborative for Academic, Social, and Emotional Learning; 2008, p: 26. [Link]

17. Zins JE, Weissberg RP, Wang MC, Walberg HJ. Building academic success on social and emotional learning: What does the research say? New York, NY, US: Teachers College Press; 2004. [Link]

18. Axelrod J. Collaborative for academic, social and emotional learning (CASEL). In: Clauss-Ehlers CS, editor. Encyclopedia of cross-cultural school psychology. Boston, MA: Springer US; 2010, pp: 232-233. [Link]

19. Merrell KW, Carrizales D, Feuerborn L, Gueldner BA, Tran OK. Strong kids-Grades 6-8: a social and emotional learning curriculum. Baltimore, MD, US: Paul H Brookes Publishing; 2007, pp: 69-346. [Link]

20. Merrell KW. Linking prevention science and social and emotional learning: the Oregon resiliency project. Psychol Sch. 2010; 47(1): 55-70. [Link]

21. Stoiber KC. Translating knowledge of socialemotional learning and evidence-based practice into 
responsive school innovations. J Educ Psychol Consult. 2011; 21(1): 46-55. [Link]

22. Greenberg MT, Domitrovich CE, Weissberg RP, Durlak JA. Social and Emotional Learning as a Public Health Approach to Education. Future Child. 2017; 27(1): 13-32. [Link]

23. Saelhof J. Examining the promotion of school connectedness through extracurricular participation [Master Thesis]. [Saskatoon, Canada]: Department of Educational Psychology and Special Education, University of Saskatchewan; 2009. [Link]

24. Zins JE, Elias MJ. Social and emotional learning: promoting the development of all students. J Educ Psychol Consult. 2007; 17(2-3): 233-255. [Link]

25. Zins JE, Weissberg RP, Wang MC, Walberg HJ. Building academic success on social and emotional learning: What does the research say? New York, NY, US: Teachers College Press; 2004. [Link]

26. Domitrovich CE, Durlak JA, Staley KC, Weissberg RP. Social-emotional competence: an essential factor for promoting positive adjustment and reducing risk in school children. Child Dev. 2017; 88(2): 408-416. [Link]

27. Dymnicki A, Sambolt M, Kidron Y. Improving college and career readiness by incorporating social and emotional learning. College and Career Readiness and Success Center; 2013. [Link]

28. Durlak JA, Weissberg RP, Dymnicki AB, Taylor RD, Schellinger KB. The impact of enhancing students' social and emotional learning: a meta-analysis of school-based universal interventions. Child Dev. 2011; 82(1): 405-432. [Link]

29. Cueto S, Guerrero G, Sugimaru C, Zevallos AM. Sense of belonging and transition to high schools in Peru. Int J Educ Dev. 2010; 30(3): 277-287. [Link]
30. Willms JD. Student engagement at school: a sense of belonging and participation. Paris: Organisation for Economic Co-operation and Development; 2003, pp: 1-79. [Link]

31. Clinton AB, Edstrom L, Mildon HA, Davila L. Social emotional learning in a Guatemalan preschool sample: Does socioeconomic status moderate the effects of a school-based prevention program? Sch Psychol Int. 2015; 36(1): 18-35. [Link]

32. Brew C, Beatty B, Watt AP. Measuring students' sense of connectedness with school. In: Australian Association for Research in Education Annual Conference, Melbourne, Australia; 2004, pp: 1-22. [Link]

33. Makian RS, Kalantar kushe SM. Normalizing sense of belonging to school questionnaire and its relationship with academic burnout and achievement motivation among Persian students. Quarterly of Educational Measurement. 2015; 5(20): 119-138. [Persian]. [Link]

34. Carrizales-Engelmann D, Feuerborn L, Gueldner B, Tran O, Merrell K. Merrell's strong kids, grades 6-8: a social and emotional learning curriculum. Baltimore, MD: Brookes Publishing; 2016. [Link]

35. Whitcomb SA. Strong start: impact of direct teaching of a social emotional learning curriculum and infusion of skills on emotion knowledge of first grade students [PhD Thesis]. [Oregon, United States]: The Office of Research, Innovation and Graduate Education, Oregon University; 2009, p: 117. [Link]

36. Shultz KS, Whitney DJ, Zickar MJ. Measurement theory in action: case studies and exercises. Second edition. New York: Routledge; 2013. [Link] 